\title{
Stable isotope paleoclimatology of the earliest Eocene using kimberlite-hosted mummified wood from the Canadian Subarctic
}

\author{
B. A. Hook ${ }^{1}$, J. Halfar ${ }^{2}$, Z. Gedalof ${ }^{3}$, J. Bollmann ${ }^{1}$, and D. J. Schulze ${ }^{2}$ \\ ${ }^{1}$ Department of Earth Sciences, University of Toronto, Toronto, ON M5S 3B1, Canada \\ ${ }^{2}$ Department of Chemical and Physical Sciences, University of Toronto Mississauga, Mississauga, \\ ON L5L 1C6, Canada \\ ${ }^{3}$ Department of Geography, University of Guelph, Guelph, ON N1G 2W1, Canada
}

Correspondence to: B. A. Hook (benjamin.hook@utoronto.ca)

Received: 21 October 2014 - Published in Biogeosciences Discuss.: 26 November 2014

Accepted: 29 September 2015 - Published: 16 October 2015

\begin{abstract}
The recent discovery of well-preserved mummified wood buried within a subarctic kimberlite diamond mine prompted a paleoclimatic study of the early Eocene "hothouse" (ca. 53.3 Ma). At the time of kimberlite eruption, the Subarctic was warm and humid producing a temperate rainforest biome well north of the Arctic Circle. Previous studies have estimated that mean annual temperatures in this region were $4-20^{\circ} \mathrm{C}$ in the early Eocene, using a variety of proxies including leaf margin analysis and stable isotopes $\left(\delta^{13} \mathrm{C}\right.$ and $\left.\delta^{18} \mathrm{O}\right)$ of fossil cellulose. Here, we examine stable isotopes of tree-ring cellulose at subannualto annual-scale resolution, using the oldest viable cellulose found to date. We use mechanistic models and transfer functions to estimate earliest Eocene temperatures using mummified cellulose, which was well preserved in the kimberlite. Multiple samples of Piceoxylon wood within the kimberlite were crossdated by tree-ring width. Multiple proxies are used in combination to tease apart likely environmental factors influencing the tree physiology and growth in the unique extinct ecosystem of the Polar rainforest. Calculations of interannual variation in temperature over a multidecadal time-slice in the early Eocene are presented, with a mean annual temperature (MAT) estimate of $11.4^{\circ} \mathrm{C}(1$ $\sigma=1.8^{\circ} \mathrm{C}$ ) based on $\delta^{18} \mathrm{O}$, which is $16^{\circ} \mathrm{C}$ warmer than the current MAT of the area $\left(-4.6^{\circ} \mathrm{C}\right)$. Early Eocene atmospheric $\delta^{13} \mathrm{C}\left(\delta^{13} \mathrm{C}_{\mathrm{atm}}\right)$ estimates were $-5.5( \pm 0.7) \%$ o. Isotopic discrimination $(\Delta)$ and leaf intercellular $p \mathrm{CO}_{2}$ ratio $\left(c_{\mathrm{i}} / c_{\mathrm{a}}\right)$ were similar to modern values $(\Delta=18.7 \pm 0.8 \%$; $c_{\mathrm{i}} / c_{\mathrm{a}}=0.63 \pm 0.03 \%$ ), but intrinsic water use efficiency (Early Eocene iWUE $=211 \pm 20 \mu \mathrm{mol} \mathrm{mol}^{-1}$ ) was over
\end{abstract}

twice the level found in modern high-latitude trees. Dualisotope spectral analysis suggests that multidecadal climate cycles somewhat similar to the modern Pacific Decadal Oscillation likely drove temperature and cloudiness trends on 20-30-year timescales, influencing photosynthetic productivity and tree growth patterns.

\section{Introduction}

\subsection{Warm subarctic climates of the earliest Eocene}

If anthropogenic fossil fuel burning continues unabated, $p \mathrm{CO}_{2}$ levels are expected to reach $855-1130 \mathrm{ppmV}$ by the end of the $21 \mathrm{st}$ century, leading to a $5.5 \pm 0.6^{\circ} \mathrm{C}$ temperature increase globally with nearly twice as much warming in Arctic regions (IPCC, 2013). In this "worst-case" climate change scenario, global temperatures will rapidly approach levels that have not existed on Earth for over 50 million years, since the Eocene. Greenhouse climates of the earliest Eocene were warm, with amplified warming at the poles (Greenwood and Wing, 1995), resulting from high atmospheric $p \mathrm{CO}_{2}$ levels ( 680-3300 ppmV; Schubert and Jahren, 2013). Permanent polar ice caps did not exist; instead, vast temperate rainforests spanned the Arctic (Williams et al., 2003), and Antarctica (Francis, 1988; Francis and Poole, 2002; Ivany et al., 2011). The role that these forests played in Eocene climates is unknown, because such rainforests do not currently grow north of the Arctic Circle. Estimates of mean temperatures in the Eocene Arctic are much warmer than today, but 
they range widely, from $4-20^{\circ} \mathrm{C}$, based on a variety of proxies [e.g., leaf physiognomy (Greenwood and Wing, 1995; Sunderlin et al., 2011), bacterial membrane lipids (Weijers et al., 2007) oxygen isotope ratios in fossils of Eocene fauna (Fricke and Wing, 2004; Eberle et al., 2010), and oxygen isotopes of wood cellulose (Wolfe et al., 2012)]. Estimates of climate variability would benefit modeling efforts of greenhouse climates (Huber and Caballero, 2003) of past and future warm periods, but few studies have examined seasonal and interannual fluctuations from the early Eocene (Eberle et al., 2010).

Recently, wood megafossils were discovered in kimberlite diamond mines in the Northwest Territories of Canada (Wolfe et al., 2012). Paleolatitude of the study site during the early Eocene [62 $\pm 5^{\circ} \mathrm{N}$ (McKenna, 1980; Irving and Wynne, 1991)] was only a few degrees different than the current location $\left(64^{\circ} 42^{\prime} 49^{\prime \prime} \mathrm{N}, 110^{\circ} 37^{\prime} 10^{\prime \prime} \mathrm{W}\right)$. Therefore, latitudinal influences on climate were similar between the early Eocene and today. These wood specimens are not petrified, but mummified, many containing original woody material in a slightly altered state. A previous study found that thermal alteration of this wood was low $\left(<60^{\circ} \mathrm{C}\right.$; Hook et al., 2015). FTIR spectra of mummified Piceoxylon cellulose extracts matched those of modern cellulose. Preservation of the wood was aided by their inclusion in adiabatically chilled post-eruptive kimberlite backfill after eruption at ca. $53.3 \mathrm{Ma}$ (Creaser et al., 2004). Samples of Piceoxylon Gothan 1905 wood from the Ekati Panda pipe owned by Dominion Diamond Corp. contain $\alpha$-cellulose matching the composition of modern cellulose standards (Hook et al., 2015). Therefore, we used these materials to investigate paleoclimates of the early Eocene, using a multi-proxy approach. By gathering records of annual tree-ring width and stable isotopes of $\delta^{13} \mathrm{C}$ and $\delta^{18} \mathrm{O}$ from the same tree rings, it is possible to glean more information than possible with a single proxy.

\subsection{Stable isotopes in paleoenvironmental research}

The ratio of $\delta^{18} \mathrm{O}$ in precipitation (i.e., source water $\delta^{18} \mathrm{O}_{\mathrm{sw}}$ ) has a strong positive correlation with temperature in terrestrial systems outside of the tropics: cooler (warmer) climates at higher latitudes and altitudes correspond with lower (higher) $\delta^{18} \mathrm{O}_{\text {sw }}$. This has allowed construction of isotopic maps that depict average $\delta^{18} \mathrm{O}_{\mathrm{sw}}$ across geographic regions (Bowen, 2010; Bowen and Revenaugh, 2003). Precipitation $\delta^{18} \mathrm{O}_{\mathrm{sw}}$ is influenced by temperature, but also the location of evaporative sources, and continental rainout effects. Therefore, $\delta^{18} \mathrm{O}_{\mathrm{sw}}$ has been used to reconstruct past temperatures from hydrologically sensitive archives, such as tree rings, on an annual to subannual basis (DeNiro and Epstein, 1979; McCarroll and Loader, 2004; Roden et al., 2009).

After it was demonstrated that stable isotopes within tree rings could be used as an "isotopic thermometer" of past climates (Libby and Pandolfi, 1974; Libby et al., 1976), there has been a concerted effort to develop this proxy for the purposes of reconstructing temperatures before the modern instrumental period. Mechanistic models have been developed which predict the stable oxygen isotopic composition of $\alpha$-cellulose $\left(\delta^{18} \mathrm{O}_{\text {cellulose }}\right)$ based on the isotopic ratio of source water $\left(\delta^{18} \mathrm{O}_{\mathrm{sw}}\right)$ received by the tree (Flanagan et al., 1991; Roden et al., 2000; Anderson et al., 2002). These studies have found that in addition to $\delta^{18} \mathrm{O}_{\mathrm{sw}}$, factors that affect evaporative enrichment of leaf water (e.g., relative humidity - RH) also influence $\delta^{18} \mathrm{O}_{\text {cellulose }}$. The problem with using mechanistic models in paleoenvironmental research is that many of these parameters (e.g., early Eocene RH, leaf temperature) are unknown. However, one may estimate a range of likely RH values and attain a range of likely temperature estimates based on the $\delta^{18} \mathrm{O}_{\text {cellulose }}$ (Wolfe et al., 2012; Csank et al., 2013). Another approach is a transfer function, derived from plotting $\delta^{18} \mathrm{O}_{\text {cellulose }}$ against $\delta^{18} \mathrm{O}_{\mathrm{sw}}$ from a number of samples and finding the best-fit relationship between them (Ballantyne et al., 2006; Richter et al., 2008b; Csank et al., 2013). Using this relationship, one may backcalculate an estimate of $\delta^{18} \mathrm{O}_{\mathrm{sw}}$ using $\delta^{18} \mathrm{O}_{\text {cellulose }}$ of fossil cellulose. Temperature may then be estimated from $\delta^{18} \mathrm{O}_{\mathrm{sw}}$ using a $\delta^{18} \mathrm{O}$-temperature relationship developed using isotope ratios of Eocene materials from different geographical locations (Fricke and Wing, 2004).

Other factors may have affected $\delta^{18} \mathrm{O}_{\mathrm{sw}}$ besides temperature. The modern temperature $-\delta^{18} \mathrm{O}_{\mathrm{sw}}$ relationship (Dansgaard, 1964) is different than in the Eocene because polar ice caps and glaciers are depleted in ${ }^{18} \mathrm{O}$, and in the Eocene these ${ }^{16} \mathrm{O}$-rich ice masses did not exist. Additionally, in the Eocene "equable" climate, latitudinal temperature gradients were not as steep as they are today, so condensation patterns may have been different (Greenwood and Wing, 1995; Fricke and O'Neil, 1999). Plant transpiration sends isotopically light oxygen into the atmosphere, which may be used by other plants, thus decreasing $\delta^{18} \mathrm{O}_{\text {cellulose }}$ more than would be expected from temperature effects. The amount effect also lowers $\delta^{18} \mathrm{O}_{\text {sw }}$ values through high levels of precipitation. In modern climate, this factor is more prevalent in tropical areas near the equator where heavy rainfall adds large amounts of ${ }^{16} \mathrm{O}$, thus lowering the $\delta^{18} \mathrm{O}_{\mathrm{sw}}$ received by plants.

Trees receive $\mathrm{CO}_{2}$ through stomatal apertures in the leaves. During $\mathrm{C}_{3}$ photosynthesis, trees discriminate against $\mathrm{CO}_{2}$ molecules containing ${ }^{13} \mathrm{C}$ resulting in a $\delta^{13} \mathrm{C}$ depletion in plant matter relative to ambient air. However, this effect is altered in two situations which increase $\delta^{13} \mathrm{C}$ in tree-ring records by reducing ${ }^{13} \mathrm{C}$ discrimination: (1) decreased relative humidity, leading to decreased stomatal aperture and decreased availability of ${ }^{12} \mathrm{C}$ molecules during carbohydrate fixation, and (2) increased photosynthetic rate as a result of increased sunlight availability. If a tree is growing in an arid region, hydrologic factors (e.g., vapor pressure deficit, relative humidity, precipitation) are more likely to dominate the $\delta^{13} \mathrm{C}$ signal because stomatal controls over water loss also limit $\mathrm{CO}_{2}$ intake, leading to higher $\delta^{13} \mathrm{C}$ (Saurer et al., 1995; McCarroll and Loader, 2004). When the tree receives 
more solar radiation the photosynthetic rate increases, more $\mathrm{CO}_{2}$ is required for glucose synthesis and ${ }^{13} \mathrm{C}$ discrimination is reduced, thus raising $\delta^{13} \mathrm{C}$. Clouds limit solar radiation, causing a drop in $\delta^{13} \mathrm{C}$, along with reduced $\mathrm{C}$ sequestration and photosynthetic assimilation (Alton, 2008). Therefore, records of $\delta^{13} \mathrm{C}$ from Pinus trees growing near the Arctic Circle in Fennoscandia show strong correlations with cloudiness, allowing $\delta^{13} \mathrm{C}$ from tree-ring cellulose to be used as a proxy for cloud cover (Young et al., 2010, 2012; Johnstone et al., 2013).

A common problem with studies of $\delta^{13} \mathrm{C}$ in modern tree rings is related to the Suess effect, which describes the modern day $\delta^{13} \mathrm{C}$ decline due to the addition of fossil fuel $\mathrm{CO}_{2}$ to the atmosphere (McCarroll and Loader, 2004). Because fossil fuels are derived from plant matter, which discriminates against ${ }^{13} \mathrm{C}$, the global average carbon isotope ratio $\left(\delta^{13} \mathrm{C}_{\mathrm{atm}}\right)$ has dropped from a pre-industrial average of $-6.4 \%$ to the modern average around $-8 \%$ (McCarroll and Loader, 2004; McCarroll et al., 2009). In the early Eocene (ca. $53.3 \mathrm{Ma}$ ), $\delta^{13} \mathrm{C}_{\mathrm{atm}}$ was $-5.7 \%$ o based on isotopes of benthic foraminifera sampled from North Atlantic ocean sediments in locations where surface waters sink to the ocean floor and are well mixed by the thermohaline circulation (Tipple et al., 2010). Thus, $\delta^{13} \mathrm{C}$ estimates from these benthic foraminifera record an archive of surface water productivity levels, which are influenced by $\delta^{13} \mathrm{C}_{\mathrm{atm}}$ (Zachos et al., 2001). Whereas $\delta^{13} \mathrm{C}_{\mathrm{atm}}$ varied on millennial timescales throughout the Cenozoic, it probably did not vary significantly throughout the life of the trees in this study.

Analysis of $\delta^{18} \mathrm{O}$ and $\delta^{13} \mathrm{C}$ measured simultaneously from tree-ring cellulose ("dual-isotope" analysis) may help constrain paleoclimatic signals better than a single isotopic ratio alone. As some environmental factors influence both $\delta^{18} \mathrm{O}$ and $\delta^{13} \mathrm{C}$ through stomatal controls, and other factors affect the isotopes independently, analyzing both isotopes together offers the possibility of teasing apart environmental factors. Conceptual models of dual-isotope behavior in tree rings in response to a range of environmental factors have been proposed (Scheidegger et al., 2000) and tested (Roden and Farquhar, 2012), with theorized relationships holding true in some cases. For example, factors affecting stomatal control influenced both $\delta^{18} \mathrm{O}$ and $\delta^{13} \mathrm{C}$. Changing $\mathrm{RH}$ and keeping all other variables fixed showed that $\delta^{18} \mathrm{O}$ and $\delta^{13} \mathrm{C}$ are indeed positively influenced by $\mathrm{RH}$, leading to the positive correlation between $\delta^{18} \mathrm{O}$ and $\delta^{13} \mathrm{C}$ observed in trees growing in arid regions (Saurer et al., 1995, 1997). Low RH causes $\delta^{18} \mathrm{O}$ to increase through evaporative loss of ${ }^{16} \mathrm{O}$ molecules $\left(\mathrm{H}_{2} \mathrm{O}\right.$ molecules are smaller than $\mathrm{CO}_{2}$ molecules, hence stomata have a reduced effect compared to $\left.\mathrm{CO}_{2}\right)(\mathrm{McC}$ arroll and Loader, 2004). In water-stressed trees, leaf stomata have a strong control over the signals of both isotopes (Saurer et al., 1995); therefore dual-isotope series show a positive correlation with each other through time (Saurer et al., 1997; Liu et al., 2014). However, trees that grow in moist regions are typically not water-stressed, so other factors not related to stomata are more likely to be dominant. For instance, low light treatments affected $\delta^{13} \mathrm{C}$ significantly, but not $\delta^{18} \mathrm{O}$, indicating that $\delta^{13} \mathrm{C}$ may be used as a proxy for past light levels (Roden and Farquhar, 2012). In practice, records of cloud cover in Fennoscandia match very closely to tree ring $\delta^{13} \mathrm{C}$, leading to its use as a cloud cover proxy (Young et al., 2010, 2012).

In this study, we measured tree-ring width and stable isotopes $\left(\delta^{18} \mathrm{O}\right.$ and $\left.\delta^{13} \mathrm{C}\right)$ at annual and subannual resolution from tree-ring cellulose extracted from multiple samples of Piceoxylon mummified wood. Our goal was to investigate seasonal, inter-annual, and possibly multidecadal variability in tree growth and physiological functioning in this unique ancient ecosystem. The extinct Polar Forest system is important to study, because it may allow improvements in vegetation boundary conditions in paleoclimate and future climate models, which are currently major sources of uncertainty (Huber and Caballero, 2011). For example, prodigious forest growth in the Subarctic and Arctic may have had profound implications in positive warming feedbacks, through changes in albedo and hydrologic regimes relative to today. Low albedo would have caused direct warming, while greater transpiration by trees would have increased water vapor in the Arctic atmosphere, which is a powerful greenhouse gas (Beerling and Franks, 2010; Jasechko et al., 2013). Therefore, Arctic temperature amplifications during equable climates may be partially explained by transpiration-related increases in water vapor.

\section{Methods}

\subsection{Tree-ring width measurement and cellulose extraction}

Six samples of Piceoxylon Gothan 1905 mummified wood were excavated during diamond mining operations at Ekati Panda kimberlite mine. Paleolatitude of the site during the early Eocene was $62 \pm 5^{\circ} \mathrm{N}$ (McKenna, 1980; Irving and Wynne, 1991), which is similar to the modern location $\left(64^{\circ} 42^{\prime} 49^{\prime \prime} \mathrm{N}, 110^{\circ} 37^{\prime} 10^{\prime \prime} \mathrm{W}\right)$, therefore the warm climates in this location are assumed not to be caused by lower latitude, but by other factors such as radiative forcing and climate feedbacks. The samples were surfaced, digitally scanned, and measured using a method developed specifically for mummified wood (Hook et al., 2013). Tree-ring series were crossdated using the skeleton plotting method (Stokes and Smiley, 1968), and the Dendrochronology Program Library in R (dplR; Bunn, 2008, 2010). A floating chronology of tree ring width indices (RWI; six samples, time series $n=92$ ) was created using a 100 -year spline to remove the biological growth trend from the raw ring width series to focus on the underlying climate signal. Whereas RWI is a good parameter for general growth conditions, it responds to numerous climatic factors (e.g., temperature, pre- 
cipitation, sunlight). Tree ring width data were compared with isotope data from the same tree rings using crosscorrelation analysis to test whether $\delta^{18} \mathrm{O}$ or $\delta^{13} \mathrm{C}$ had any significant associations with RWI in the same, or lagged, tree rings.

We dissected four individual tree rings (EPA3 rings 46-49) into subannual samples (ranging from $n=5$ to $n=11$ per tree ring) to capture the climatic signal from wood formed during the growing season. Along with this seasonal study we dissected entire tree rings from wood transects for an annual-resolution study (three crossdated mummified wood samples: EPA3, $n=42$; EPA4, $n=54$; EPA6, $n=43$; master chronology time series 86-year long, see the Supplement). We selected these series due to strong correlations found in the tree-ring width series overlapping portions. Kimberlite minerals were removed from the outer bark edge of samples and cross-sections ( $3 \mathrm{~cm}$ thick) were cut. Then transects were cut from the cross-sections from pith to bark, perpendicular to tree-ring boundaries. Transects were mechanically cleaned of kimberlite minerals, and then dissected into annual or subannual samples using a reflected-light microscope. Individual samples were placed in sterile glass vials and ground with a micro-pestle.

A Modified Brendel cellulose extraction method was used; heated acid hydrolysis (via strong nitric/acetic acids) at $120^{\circ} \mathrm{C}$ for $1 \mathrm{~h}$ to ensure complete delignification. Following that, we used a $2.5 \% \mathrm{NaOH}$ to remove hemicelluloses, which may have exchangeable oxygen atoms that can be replaced by ambient (modern) oxygen and bias the signal (Brendel et al., 2000; Gaudinski et al., 2005; Richter et al., 2008a; Hook et al., 2015). Stable isotope ratios were measured at the Stable Isotope Laboratory at the University of Maryland. Cellulose was converted to carbon monoxide $\mathrm{CO}$ at $1080^{\circ} \mathrm{C}$ over glassy carbon within a stream of $99.99 \% \mathrm{He}$. Sample gas was then passed through traps for $\mathrm{CO}_{2}$ and $\mathrm{H}_{2} \mathrm{O}$, and $\mathrm{CO}$ separated from $\mathrm{N}_{2}$ by gas chromatography, before isotopic analysis on Continuous-Flow Micromass/Elementar Isoprime coupled to a Costech Analytical High Temperature Generator and Elemental Combustion System (Werner et al., 1996). Carbon and oxygen isotopic data were corrected for runtime drift, amplitude dependence and scaling using widely separated working cellulose isotopic standards calibrated to international reference materials (Vienna Pee Dee Belemnite, VPDB for $\delta^{13} \mathrm{C}$, and Standard Mean Ocean Water, SMOW, for $\delta^{18} \mathrm{O}$ ). The overall precisions for the corrected data, based on replicate standard analyses, are $0.14 \%$ o for $\delta^{13} \mathrm{C}$ and $0.23 \%$ for $\delta^{18} \mathrm{O}$.

\subsection{Oxygen isotope analysis}

To estimate early Eocene temperatures, the stable isotopic composition of $\delta^{18} \mathrm{O}$ in tree ring cellulose $\left(\delta^{18} \mathrm{O}_{\text {cellulose }}\right)$ was used to estimate $\delta^{18} \mathrm{O}$ of source water $\left(\delta^{18} \mathrm{O}_{\text {sw }}\right)$ using mechanistic models developed with modern plants (Roden et al., 2000). The Roden cellulose model uses a leaf-water isotope $\left(\delta^{18} \mathrm{O}_{\mathrm{wl}}\right)$ model to predict $\delta^{18} \mathrm{O}_{\mathrm{wl}}$ from $\delta^{18} \mathrm{O}_{\mathrm{sw}}$ (Flanagan et al., 1991) using Eq. 1:

$\delta^{18} \mathrm{O}_{\mathrm{wl}}=\left\{\left(\alpha\left[\alpha_{\mathrm{k}} \cdot R_{\mathrm{wx}}\left(e_{\mathrm{i}}-e_{\mathrm{a}} / e_{\mathrm{i}}\right)+R_{\mathrm{wa}}\left(e_{\mathrm{a}} / e_{\mathrm{i}}\right)\right] / 0.0020052\right)-1\right\}$,

$.1000 \%$ o

where $R_{\mathrm{wx}}$ and $R_{\mathrm{wa}}$ are the molar ratios of ${ }^{18} \mathrm{O} /{ }^{16} \mathrm{O}$ in xylem water, and atmospheric water, respectively, $\alpha$ is the fractionation factor for liquid-vapor equilibrium of water, which depends on temperature (Majoube, 1971), $\alpha_{\mathrm{k}}$ is the kinetic fractionation of water $\left({ }^{16} \mathrm{O} /{ }^{18} \mathrm{O}=1.0285\right)$, and $e_{\mathrm{i}}$ and $e_{\mathrm{a}}$ are the partial pressures of water vapor in leaf intercellular spaces and in the atmosphere, respectively. Through a sensitivity analysis we found that the model was insensitive to changes in temperature, so we used optimal leaf temperature during photosynthesis $\left(21.4^{\circ} \mathrm{C}\right.$, Helliker and Richter, 2008 ) for calculation of $\alpha$. Relative humidity (RH), however, had a large influence on the outcome, so we used a range of likely RH values in a temperate rainforest $(64,77,83 \%)$. The Roden et al. (2000) model uses the Flanagan et al. (1991) leaf-water model to predict $\delta^{18} \mathrm{O}_{\text {cellulose }}$ following Eq. (2):

$\delta^{18} \mathrm{O}_{\text {cellulose }}=f_{\mathrm{O}} \cdot\left(\delta^{18} \mathrm{O}_{\mathrm{wx}}+\varepsilon_{\mathrm{O}}\right)+\left(1-f_{\mathrm{O}}\right) \cdot\left(\delta^{18} \mathrm{O}_{\mathrm{wl}}+\varepsilon_{\mathrm{O}}\right)$.

Here $f_{\mathrm{O}}$ is the fraction of carbon-bound oxygen that is subject to isotopic exchange $(42 \%), \delta^{18} \mathrm{O}_{\mathrm{wx}}$ is the isotope ratio of xylem water and $\varepsilon_{\mathrm{O}}$ is the biochemical fractionation factor related to conversion of sugar into cellulose $(27 \%$ ). Xylem water is used as a close approximation to source water, which is valid because no fractionation occurs between soil water and the transference to xylem water (Barbour et al., 2002). Anderson et al. (2002) created a simplified model that combined the Flanagan et al. (1991) leaf-water model with the Roden et al. (2000) cellulose model, and reversed it to solve for $\delta^{18} \mathrm{O}_{\mathrm{sw}}$ using $\delta^{18} \mathrm{O}_{\text {cellulose }}$ following Eq. 3:

$\delta^{18} \mathrm{O}_{\mathrm{sw}} \approx \delta^{18} \mathrm{O}_{\text {cellulose }}-(1-f) \cdot(1-h)+\left(\alpha+\alpha_{\mathrm{k}}\right)-\varepsilon_{\mathrm{O}}$.

Here $f$ is a dampening factor related to isotopic fractionations between photosynthate and stem water and $h$ is relative humidity. In addition to these mechanistic models, we used several transfer functions developed using modern tree-ring $\delta^{18} \mathrm{O}_{\text {cellulose }}$ and its relationship to $\delta^{18} \mathrm{O}_{\text {sw }}$ (Ballantyne et al., 2006; Richter et al., 2008b; Csank et al., 2013). A temperature $-\delta^{18} \mathrm{O}_{\mathrm{sw}}$ relationship developed for the Eocene was used to estimate the mean annual temperature (MAT) based on $\delta^{18} \mathrm{O}_{\mathrm{sw}}$ (Fricke and Wing, 2004; Table 1).

\subsection{Carbon isotope analysis}

Isotopic discrimination against ${ }^{13} \mathrm{C}$ during photosynthesis has been modeled by Farquhar et al. $(1982,1989)$ following Eq. (4):

$\Delta=a+(b-a) c_{\mathrm{i}} / c_{\mathrm{a}}$,

where $\Delta$ is the discrimination against ${ }^{13} \mathrm{C}, a$ is the fractionation due to diffusion through air $(4.4 \% o), b$ is the fractionation due to carboxylation by RuBisCO (27-30\%), $c_{\mathrm{i}}$ and 
Table 1. Summary of equations used in oxygen isotope temperature reconstruction. Mechanistic models and transfer functions used to

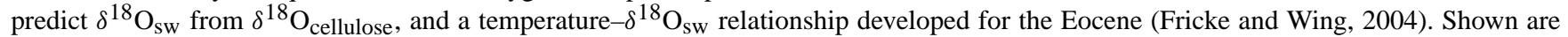
each equation and the reference on which it is based.

\begin{tabular}{|c|c|c|}
\hline Type of analysis & $\begin{array}{l}\text { Used to } \\
\text { calculate }\end{array}$ & Reference \\
\hline \multicolumn{3}{|l|}{ Mechanistic models } \\
\hline$\delta^{18} \mathrm{O}_{\mathrm{wl}}=\left\{\left(\alpha\left[\alpha_{\mathrm{k}} \cdot R_{\mathrm{wx}}\left(e_{\mathrm{i}}-e_{\mathrm{a}} / e_{\mathrm{i}}\right)+R_{\mathrm{wa}}\left(e_{\mathrm{a}} / e_{\mathrm{i}}\right)\right] / 0.0020052\right)-1\right\} \cdot 1000$ & $\delta^{18} O_{\mathrm{wl}}$ & Flanagan et al. (1991) \\
\hline$\delta^{18} \mathrm{O}_{\text {cellulose }}=f_{\mathrm{O}} \cdot\left(\delta^{18} \mathrm{O}_{\mathrm{wx}}+\varepsilon_{\mathrm{O}}\right)+\left(1-f_{\mathrm{O}}\right) \cdot\left(\delta^{18} \mathrm{O}_{\mathrm{wl}}+\varepsilon_{\mathrm{O}}\right)$ & $\delta^{18} O_{\mathrm{wx}}$ & Roden et al. $(2000)^{\mathrm{a}}$ \\
\hline$\delta^{18} \mathrm{O}_{\mathrm{sw}} \approx \delta^{18} \mathrm{O}_{\text {cellulose }}-(1-f) \cdot(1-h)+\left(\alpha+\alpha_{\mathrm{k}}\right)-\varepsilon_{\mathrm{O}}$ & $\delta^{18} O_{\mathrm{sw}}$ & Anderson et al. (2002) \\
\hline \multicolumn{3}{|l|}{ Transfer functions } \\
\hline$\delta^{18} \mathrm{O}_{\mathrm{sw}}=312.75 \cdot e^{\left(-0.13 \cdot \delta^{18} \mathrm{O}_{\text {cellulose }}\right)}$ & $\delta^{18} O_{\mathrm{sw}}$ & Ballantyne et al. (2006) \\
\hline$\delta^{18} \mathrm{O}_{\mathrm{sw}}=\left(\delta^{18} \mathrm{O}_{\text {cellulose }}-35.11\right) / 0.59$ & $\delta^{18} O_{\mathrm{sw}}$ & Richter et al. $(2008 b)^{b}$ \\
\hline$\delta^{18} \mathrm{O}_{\mathrm{sw}}=\left(\delta^{18} \mathrm{O}_{\text {cellulose }}-33.2045\right) / 0.6109$ & $\delta^{18} O_{\mathrm{sw}}$ & Csank et al. $(2013)^{\mathrm{b}}$ \\
\hline$\delta^{18} \mathrm{O}_{\mathrm{sw}}=-0.01 T^{2}+T-22.91$ & $T\left({ }^{\circ} \mathrm{C}\right)$ & Fricke and Wing $(2004)^{\mathrm{c}}$ \\
\hline
\end{tabular}

$c_{\mathrm{a}}$ are the partial pressures of $\mathrm{CO}_{2}$ in the leaf intercellular spaces and atmosphere, respectively. Additionally, $\Delta$ can be calculated by Eq. (5; Farquhar et al., 1989):

$\Delta=\left(\delta^{13} \mathrm{C}_{\mathrm{atm}}-\delta^{13} \mathrm{C}_{\mathrm{p}}\right) /\left(1+\delta^{13} C_{\mathrm{p}} / 1000\right)$,

where $\delta^{13} \mathrm{C}_{\mathrm{atm}}$ and $\delta^{13} \mathrm{C}_{\mathrm{p}}$ are the carbon isotope ratios of atmospheric $\mathrm{CO}_{2}$ and bulk plant tissue, respectively. To esti-

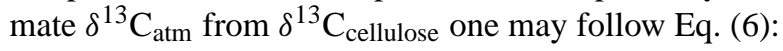

$\delta^{13} \mathrm{C}_{\mathrm{atm}}=\Delta+\delta{ }^{13} \mathrm{C}_{\text {cellulose }}-\varepsilon_{\mathrm{pc}}$,

where $\varepsilon_{\mathrm{pc}}$ is the carbon isotopic difference (\%o) between cellulose $\left(\delta^{13} C_{\text {cellulose }}\right)$ and bulk plant matter $\left(\delta^{13} C_{\mathrm{p}}\right)$ (i.e., $\varepsilon_{\mathrm{pc}}=\delta^{13} C_{\text {cellulose }}-\delta^{13} C_{\mathrm{p}}$ ). Carbon isotope ratios of cellulose are typically 2-5\%o higher (more enriched) than $\delta^{13} \mathrm{C}$ of bulk plant tissue in the modern $\mathrm{pCO}_{2}$ environment (Barbour et al., 2002). Early Eocene-aged mummified Piceoxylon $\varepsilon_{\mathrm{pc}}$ values fell within the modern $\varepsilon_{\mathrm{pc}}$ range, and are used in our calculations $\left(\varepsilon_{\mathrm{pc}}=3 \%\right.$; Hook et al., 2015). The parameters $a$ and $b$ in the Farquhar et al. (1982) model (Eq. 4) are usually assumed to be constant, making $\Delta$ dependent on the ratio of $p \mathrm{CO}_{2}$ inside vs. outside the leaf $\left(c_{\mathrm{i}} / c_{\mathrm{a}}\right)$, which is unknown for the Eocene. However, $\Delta$ could be estimated using $\delta^{13} \mathrm{C}_{\mathrm{atm}}$ from Eq. (6), then $c_{\mathrm{i}} / c_{\mathrm{a}}$ by Eq. (4). The relationship between carbon isotope ratios of plant matter $\left(\delta^{13} \mathrm{C}_{\mathrm{p}}\right)$ and the atmosphere $\left(\delta^{13} \mathrm{C}_{\mathrm{atm}}\right)$ derived by Arens et al. (2000), following Eq. (7):

$\delta^{13} \mathrm{C}_{\mathrm{atm}}=\left(\delta^{13} \mathrm{C}_{\text {cellulose }}+18.72-\varepsilon_{\mathrm{pc}}\right) / 1.05$.

Lomax et al. (2012) estimated the $\delta^{13} C_{\text {atm }}-\delta^{13} C_{\text {cellulose }}$ relationship using growth chamber experiments, given by Eq. (8):

$\delta^{13} \mathrm{C}_{\mathrm{atm}}=\left(\delta^{13} \mathrm{C}_{\text {cellulose }}+15.71-\varepsilon_{\mathrm{pc}}\right) / 1.288$.
As these equations are both based on empirical data sets that do not cover the full range of early Eocene $p \mathrm{CO}_{2}$, they may not represent the "true" relationship between $\delta^{13} \mathrm{C}_{\mathrm{atm}}$ and $\delta^{13} \mathrm{C}_{\mathrm{p}}$ at all $c_{\mathrm{a}}$ levels. Therefore, we analyze them both as a possible range of values, and also take the arithmetic mean of Eqs. (7) and (8), which is given by Eq. (9):

$\delta^{13} \mathrm{C}_{\mathrm{atm}}=\left(\delta^{13} \mathrm{C}_{\text {cellulose }}+14.37-\varepsilon_{\mathrm{pc}}\right) / 1.1569$.

To calculate $c_{\mathrm{i}} / c_{\mathrm{a}}$ we substituted $\delta^{13} \mathrm{C}_{\mathrm{atm}}$ from Eqs. (7), (8), and (9) into the $\delta^{13} \mathrm{C}_{\mathrm{atm}}$ term of Eq. (6) and solved for $\Delta$, then solved for $c_{\mathrm{i}} / c_{\mathrm{a}}$ by rearranging Eq. (4), using $\Delta$ estimates and standard fractionation constants $(a=4.4, b=27$; Farquhar et al., 1989). We then calculated intrinsic water use efficiency (iWUE), a measure of carbon gained vs. water lost through stomatal apertures (Farquhar et al., 1982, 1989; Gagen et al., 2011) from Eq. (10), using $c_{\mathrm{a}}=915 \mathrm{ppmV}$ (Schubert and Jahren, 2013).

$\mathrm{iWUE}=\left(c_{\mathrm{a}}-c_{\mathrm{i}}\right) / 1.6$.

\subsection{Dual-isotope analysis}

Oxygen isotopes in cellulose are typically enriched by 20 to $30 \%$, whereas carbon isotopes are depleted $(-20$ to $-25 \%$ o range). Therefore, to make the isotopes more comparable, both data sets were normalized $($ mean $=0$, variance $=1)$ and plotted together on one axis. The normalized isotope time series were then summed (subtracted) to amplify (suppress) isotopic variability common to both isotopes, and suppress (amplify) factors to which the isotopes do not respond in a similar manner. For instance, changes in stomatal conductance (e.g., due to changes in relative humidity or drought) affect both isotopes, so if variance related to stomatal conductance is large, the $\delta^{13} \mathrm{C}$ and $\delta^{18} \mathrm{O}$ time series should 
be positively correlated and vary in-phase with each other (Saurer et al., 1997). Any variance in the dual-isotope series that is not explained by this positive correlation is likely related to other factors. A factor that would likely influence

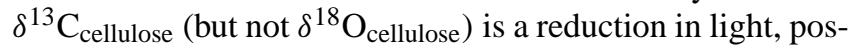
sibly by cloud coverage (Johnstone et al., 2013). On the other hand, $\delta^{18} \mathrm{O}_{\text {sw }}$ would significantly affect $\delta^{18} \mathrm{O}_{\text {cellulose }}$ (but not $\delta^{13} \mathrm{C}_{\text {cellulose; }}$ Ferrio and Voltas, 2005).

One way to amplify an environmental signal common to two proxies is addition. Adding the normalized series together $\left(\Sigma_{Z \text {-score }}\right)$ amplifies the in-phase components of the variance, and suppresses the out-of-phase components. Conversely, subtracting the dual-isotope series from each other $\left(\Delta_{Z}\right.$-score $)$ amplifies the out-of-phase components of the variance and suppresses the in-phase components. Therefore, theoretically the $\Sigma_{\mathrm{Z} \text {-score }}$ series should reflect variability associated with hydrologic factors related to stomatal conductance (e.g., relative humidity), and the $\Delta_{\mathrm{Z} \text {-score }}$ series should reflect variability related to sunlight and $\delta^{18} \mathrm{O}$ of source water. Spectral analysis was conducted [Multi-Taper Method, MTM (Mann and Lees, 1996); Singular Spectral Analysis, SSA (Vautard and Ghil, 1989); kSpectra software] on the raw

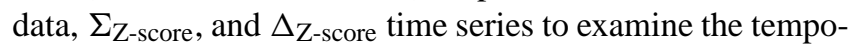
ral power spectra.

\section{Results and discussion}

\subsection{Subannual-resolution study}

Days were long in the subarctic Eocene summer $\left(\sim 19 \mathrm{hday}^{-1}\right.$ at summer solstice), allowing high rates of photosynthesis, provided solar radiation was not obscured by clouds. In the subannual study, the intra-annual series generally showed a rise and fall pattern throughout the growing season, suggesting that this wood is of a persistent-leaved species (upper two graphs in Fig. 1; Barbour et al., 2001). Earlywood cellulose in deciduous species is isotopically enriched in $\delta^{13} \mathrm{C}$ compared to persistent-leaves species, due to the use of carbohydrates stored in parenchyma over the dormant season (Jahren and Sternberg, 2008). Changes in relative humidity $(\mathrm{RH})$ may explain a positive slope in a scatterplot of $\delta^{18} \mathrm{O}$ and $\delta^{13} \mathrm{C}$ (Roden and Farquhar, 2012); theoretically, lowest RH (highest $T$ ) would be in midsummer when the continuous light regime is near its peak (Fig. 2). However, other factors besides RH probably affected the isotope signals in most years not described by a simple rise and fall pattern along the RH slope. Tree ring (TR) 46 displayed a small range in $\delta^{18} \mathrm{O}\left(1.7 \%\right.$ ) and $\delta^{13} \mathrm{C}(0.4 \%$ ) throughout the year possibly indicating mild homogenous climate during that year (Fig. 2). On the other hand, years with high solar radiation but lower temperature variation may have raised the $\delta^{13} \mathrm{C}$ without significantly altering $\delta^{18} \mathrm{O}$, as in the end of the season in TR 47.
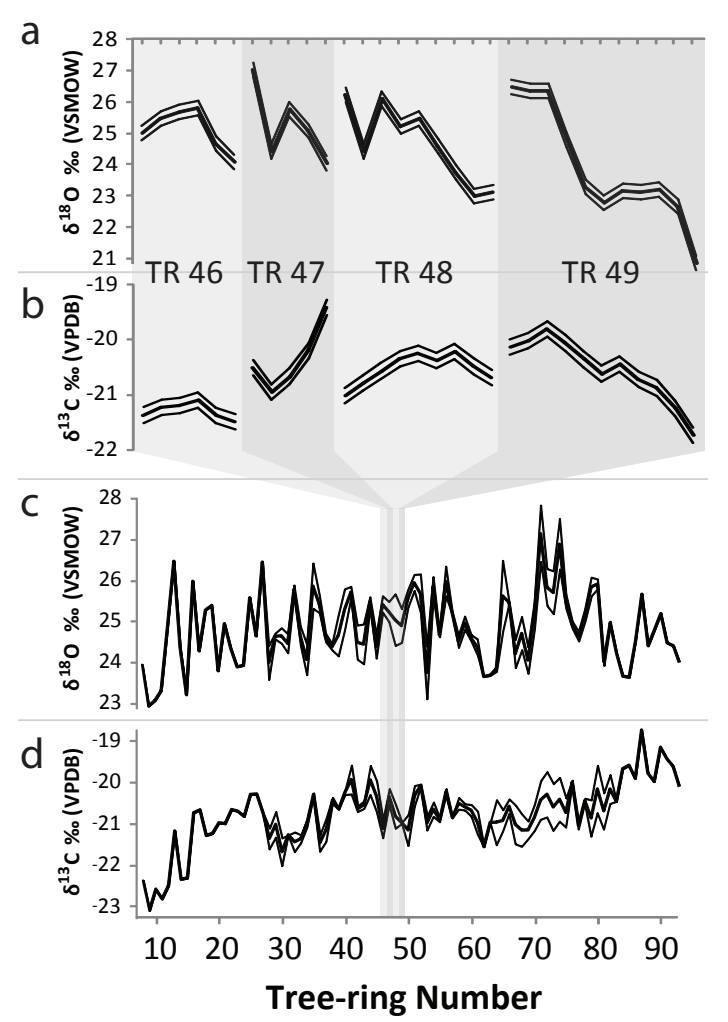

Figure 1. Subannual and annual-resolution time series records of tree-ring cellulose $\delta^{18} \mathrm{O}$ and $\delta^{13} \mathrm{C}$. Subannual resolution (a) $\delta^{18} \mathrm{O}$ record, and (b) $\delta^{13} \mathrm{C}$ record, of four tree rings (TR 46-49). Lines above and below the measured values (bold center lines) show the analytical uncertainty $\left(0.14 \%\right.$ for $\delta^{13} \mathrm{C}, 0.23 \%$ for $\left.\delta^{18} \mathrm{O}\right)$. Annual resolution (c) $\delta^{18} \mathrm{O}$ record, and (d) $\delta^{13} \mathrm{C}$ record $(n=86)$. Bold lines show mean isotope values of annual-resolution study, thin lines above and below mean values show minimum and maximum isotope values of successfully crossdated tree-ring transects (TR 2863, 64-82).

The range in $\delta^{18} \mathrm{O}$ in ring $49(5.6 \%$ ) was significantly larger than the average $\delta^{18} \mathrm{O}$ range $(<4 \%$ ) in modern climates (Barbour et al., 2001). Possible reasons for the extreme seasonal range in TR 49 include an amount effect due to progressively larger amounts of late summer rains (Dansgaard, 1964), isotopically light source water recycled from the enclosed freshwater Arctic Ocean (Brinkhuis et al., 2006), or depleted water from forest transpiration (Jaseschko et al., 2013) reforming as precipitation. The first explanation (amount effect) is appealing due to the large tree-ring width seen in TR 49, which may have benefitted from long lateseason rains, but all factors could have contributed to this large $\delta^{18} \mathrm{O}$ range. Traumatic resin ducts were observed in TR 47 and 49, and these rings showed an irregular scatterplot pattern (Fig. 2). Therefore, it is also possible that disturbance (e.g., defoliation by insects) contributed to interruptions in these patterns. However, such disturbances are unlikely to substantially alter the climate signal on an an- 


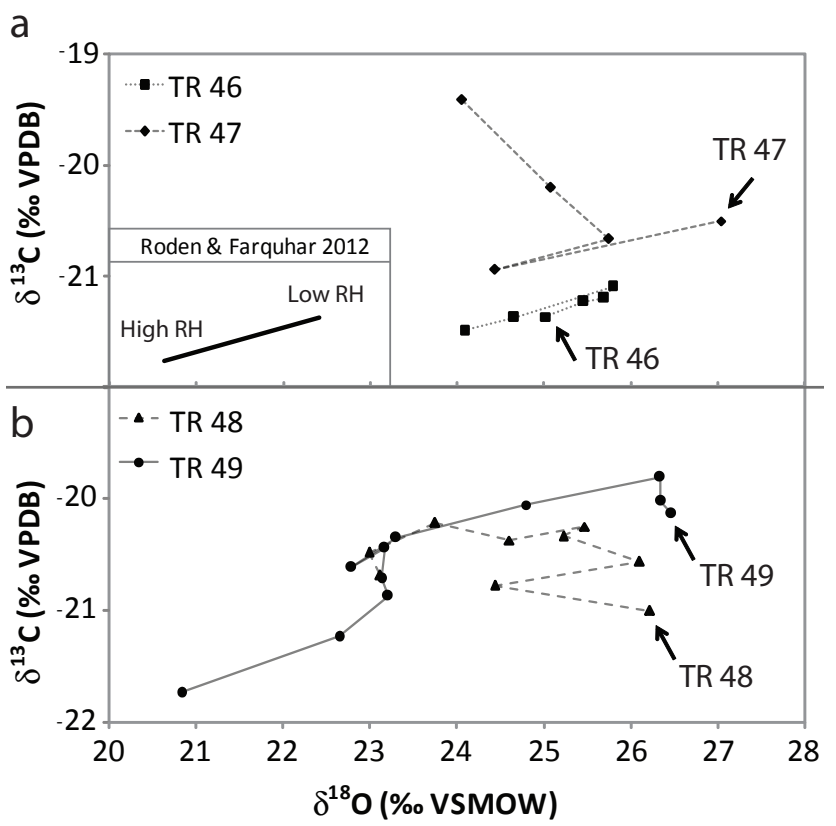

Figure 2. Scatterplots of dual-isotope data for four tree rings (TR 46-49), showing trends of $\delta^{18} \mathrm{O}$ and $\delta^{13} \mathrm{C}$ within a growing season. Arrows point to the start of each numbered tree ring (earlywood), lines connect to consecutive samples (latewood) within each tree ring. Upper graph contains first two tree rings, and lower graph the third and fourth rings. Inset box in upper graph shows average low to high $\mathrm{RH}$ for Pinus radiata D. Don (after Roden and Farquhar, 2012). Low-to-high RH dual-isotope relationship: $\left[\delta^{13} \mathrm{C}=0.22 \times \delta^{18} \mathrm{O}-31.31\right]$. Scale is the same for inset graph, but actual values of Roden and Farquhar $\left(2012 ; \delta^{18} \mathrm{O}\right.$ low RH $=$ $29.26 \%$ o, $\delta^{18} \mathrm{O}$ high $\mathrm{RH}=26.9 \%$; $\delta^{13} \mathrm{C}$ low $\mathrm{RH}=-24.86 \%$, $\delta^{13} \mathrm{C}$ high $\mathrm{RH}=-25.38 \%$ o) do not correspond with these axes.

nual basis, as modern trees do not show a strong isotopic response to disturbance from natural insect defoliation (Daux et al., 2011) or extreme experimental defoliation (Simard et al., 2012). Another factor in seasonal changes in $\delta^{13} \mathrm{C}$ is an increase in $\delta^{13} \mathrm{C}$ during peak growing season, when plants preferentially remove ${ }^{12} \mathrm{C}$ from the atmosphere (McCarroll and Loader, 2004).

\subsection{Annual-resolution study}

\subsubsection{Tree-ring width and isotope correlations}

Tree ring growth was prodigious in the earliest Eocene Subarctic [mean tree ring width for the six crossdated Piceoxylon samples ranged from $1.88-2.19 \mathrm{~mm}$ ( $\sigma$ range $=0.65-$ $0.76, n=92)$ ]. Ring width series in this study were sensitive enough for crossdating (mean sensitivity values $=0.20$ 0.36). The overlapping tree-ring width (TRW) sequences from the wood fragments were marginally positively correlated, supporting the idea that the trees were subjected to similar climatic conditions (EPA3 vs. EPA4, $R=0.38, p=0.04$, $n=30$ ). In fact, some TRW series were so similar that they may have originated from the same tree, and were separated during burial or excavation (EPA4 vs. EPA6, $R=0.90$, $p<0.0001, n=35$ ). Because these six samples are all of the same species, growing in the same area, we consider the master chronology produced here to be a reflection of local climate and ontogenetic influences on the trees. TRW series were detrended to remove ontogenetic (biological growth) patterns and focus on the climate signal. However, many factors may influence TRW, so we measured stable isotopes from a subset of tree rings to reconstruct specific climatic influences (e.g., temperature, solar radiation).

Stable isotopes were measured from three crossdated Piceoxylon samples (EPA3, EPA4, and EPA6). Annualresolution stable oxygen isotope $\left(\delta^{18} \mathrm{O}\right)$ series were strongly correlated in both overlapping sections (EPA3 vs. EPA4, $R=0.78, p<0.0001, n=22$; EPA4 vs. EPA6, $R=0.85$, $p<0.0001, n=31$ ) (lower two graphs in Fig. 1). In one of the overlapping sections, $\delta^{13} \mathrm{C}$ was strongly correlated (EPA3 vs. EPA4, $R=0.73, p<0.0001, n=22$ ), but this was not the case in the other overlapping section (EPA4 vs. EPA6, $R=0.01, p=0.97, n=31$ ). Both the RWI and $\delta^{18} \mathrm{O}$ records correlate strongly in this section so it is unknown why $\delta^{13} \mathrm{C}$ does not. Cross-correlation analysis of RWI and $\delta^{18} \mathrm{O}$ isotope series found marginally significant relationships $(p<0.05)$ when lagged by 1 or 2 years, suggesting that climatic conditions from the previous year or two significantly influence tree-ring width $\left[\delta^{18} \mathrm{O}\right.$ lagged -1 year before RWI $(R=0.27, p=0.02, n=84), \delta^{18} \mathrm{O}$ lagged -2 years before RWI $(R=0.22, p=0.04, n=83)$ ]. Additionally, a marginally positive correlation was found when $\delta^{13} \mathrm{C}$ was lagged +2 with regard to RWI $(R=0.23, p=0.04, n=83)$. This correlation may indicate that increased tree-ring growth is associated with increased foliage production in the following years, thus leading to an increase in photosynthetic capacity and hence an increase in $\delta^{13} \mathrm{C}$.

Annual-resolution master chronologies of both isotope series $\left(\delta^{13} \mathrm{C}\right.$ and $\left.\delta^{18} \mathrm{O}\right)$ were produced by taking the arithmetic mean of overlapping segments. The $\delta^{13} \mathrm{C}$ and $\delta^{18} \mathrm{O}$ master chronologies were positively correlated (Pearson's $R=0.36$, $P<0.001, n=86$; Figs. 1 and 3). However, the first four to eight tree rings were noticeably lower in $\delta^{13} \mathrm{C}$ than the rest of the tree rings, presumably due to a juvenile effect in which growth conditions are different (e.g., shadier) than mature trees. If these four to eight rings are removed from analysis, the isotopes are no longer correlated (first four rings removed, Pearson's $R=0.17, P=0.12, n=82$; first eight rings removed Pearson's $R=0.14, P=0.22, n=78$ ). No correlation between the isotopes implies that stomatal conductance was less important than other climatic factors, suggesting that humid climates prevailed (Saurer et al., 1995). A previous study of middle Eocene (ca. $45 \mathrm{Ma}$ ) humidity found very high RH levels (80-100\%) by the end of the season in Metasequoia wood from high-Arctic Axel Heiberg Island ( $77^{\circ} \mathrm{N}$ paleolatitude; Jahren and Sternberg, 2008). Therefore, 


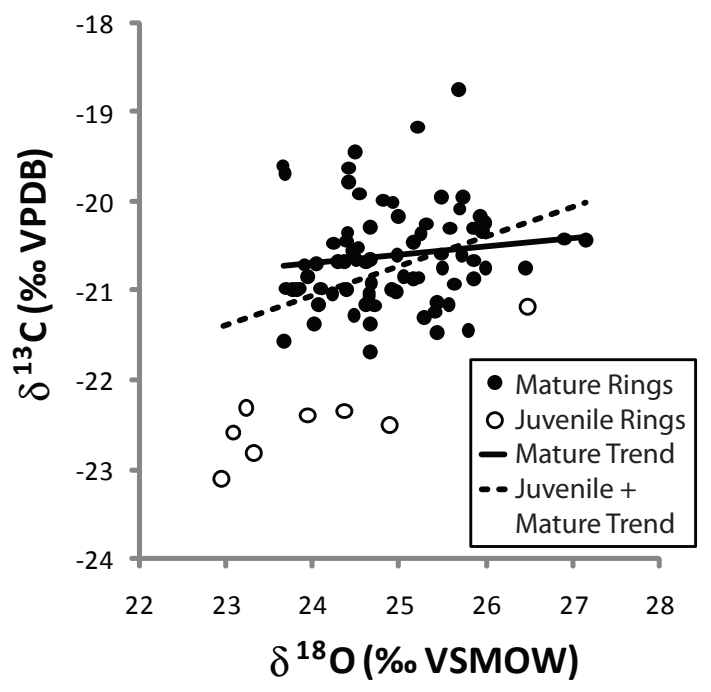

Figure 3. Correlation analysis of dual-isotope annual data set. $\delta^{18} \mathrm{O}$ and $\delta^{13} \mathrm{C}$ were significantly positively correlated (dashed trendline; Pearson's $R=0.36, P<0.001, n=86$ ). However, if the first $4-8$ "juvenile" tree rings (hollow circles) are removed from analysis, the remaining samples (filled circles) are not correlated (solid trendline; Pearson's $R=0.14, P=0.22, n=78$ ).

it is likely that high humidity with low variability existed at the Lac de Gras site during the early Eocene.

\subsubsection{Oxygen isotope analysis}

Using the annual-resolution $\delta^{18} \mathrm{O}$ record, a range of temperature estimates was produced using the mechanistic models and transfer functions (Table 1). However, it is unknown which of these estimates is closest to actual Eocene temperatures. We estimated temperature based on different possible relative humidity $(\mathrm{RH})$ levels $(64,77,83 \%)$, as in Wolfe et al. (2012) and Csank et al. (2013), and then calculated mean, standard deviation, $90 \%$ confidence intervals, minimum and maximum of all models (Figs. 4 and 5). Temperatures were generally warm according to this proxy record, staying above zero in the $90 \%$ confidence interval; the range was $3.5-$ $16.4{ }^{\circ} \mathrm{C}(n=4)$, with a mean of $10.9^{\circ} \mathrm{C}\left(1 \sigma=3.0^{\circ} \mathrm{C}\right.$; black line in Fig. 4). Warm month mean temperatures (WMMT) would therefore be at the higher end of this growing season range $\left(\sim 16.4 \pm 3.0^{\circ} \mathrm{C}\right)$, which is in agreement with published records of high Arctic seasonal temperatures (19$20^{\circ} \mathrm{C}$, Eberle et al., 2010). Because tree-ring growth ceases during the winter, cold month mean temperatures (CMMT) cannot be directly calculated with this archive. However, we may estimate CMMT in comparison to mean annual temperature (MAT) using independent estimates based on apatite of bowfin (amiid) fish that grow year-round suggesting CMMT of $0-3.5^{\circ} \mathrm{C}$ and an MAT of $8^{\circ} \mathrm{C}$ (Eberle et al., 2010). In our annual study, the mean of all of the methods (black line in Fig. 5) ranged from $7.5-16.6^{\circ} \mathrm{C}$, with a

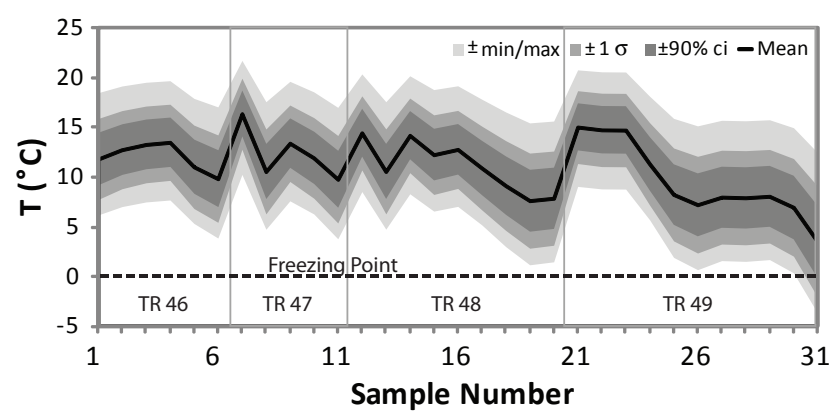

Figure 4. Mean temperature $\left({ }^{\circ} \mathrm{C}\right)$ of subannual data based on all $\delta^{18} \mathrm{O}$-temperature reconstructions. Mean of all reconstructions (black line) is bracketed by $90 \%$ confidence interval $( \pm 90 \% \mathrm{ci}$, dark gray fill), one standard deviation ( $\pm 1 \sigma$, medium gray fill), and minimum/maximum ( $\pm \mathrm{min} / \mathrm{max}$, light gray fill). Freezing point is shown by dashed line.

mean of $11.4^{\circ} \mathrm{C}\left(1 \sigma=1.8^{\circ} \mathrm{C}\right.$; Table 2$)$. This would suggest a CMMT of $\sim 3.4-6.9^{\circ} \mathrm{C}$ during the earliest Eocene based on the difference between CMMT and MAT found by Eberle et al. (2010) applied to our MAT estimate. The standard deviation of all methods was $4.1{ }^{\circ} \mathrm{C}$, and the $90 \%$ confidence interval was $2.7^{\circ} \mathrm{C}$ (Fig. 5).

A mean temperature of $11.4{ }^{\circ} \mathrm{C}$ is close to other estimates of early Eocene MAT based on independent proxies (e.g., leaf margin analysis: $11-14^{\circ} \mathrm{C}$, Sunderlin et al., 2011). Some of the highest MAT estimates produced $\left(>20^{\circ} \mathrm{C}\right)$ match estimates of warmest mean temperatures for the early Eocene $\left(18-20^{\circ} \mathrm{C}\right.$; Weijers et al., 2007). Our MAT estimate is $2.4^{\circ} \mathrm{C}$ higher than that of Wolfe et al. (2012; grand mean $=9^{\circ} \mathrm{C}$ ), but our mean estimate of $11.4^{\circ} \mathrm{C}$ falls within the total range of MAT estimates provided by that study $\left(7-12^{\circ} \mathrm{C}\right)$. Their study was conducted on $\delta^{18} \mathrm{O}$ and $\delta^{2} \mathrm{H}$ of cellulose from Metasequoia trees from the same kimberlite mine $(n=4)$. However, bulk wood samples were taken in that study, precluding the possibility of examining distinct years. We measured 141 individual tree rings from three crossdated treering series spanning an 86-year-long period, and there were years in our record in which the MAT estimate was as low as $9{ }^{\circ} \mathrm{C}$ as in Wolfe et al. (2012). It may be that the cellulose sampled in that study grew during these years of slightly lower MAT, or that differences of $1-3^{\circ} \mathrm{C}$ are not currently resolvable using these proxies and the values are essentially equivalent.

\subsubsection{Carbon isotope analysis}

The carbon isotopic composition of the atmosphere $\left(\delta^{13} \mathrm{C}_{\mathrm{atm}}\right)$ changes slowly over million-year timescales (largely related to plate tectonic related forcing; Zachos et al., 2001; Tipple et al., 2010). In the absence of a drastic release of atmospheric carbon such as the PaleoceneEocene Thermal Maximum this value is assumed to be constant over an average tree lifespan $(<1000$ years $)$. In this 
Table 2. Early Eocene Mean Annual Temperature (MAT) estimates based on $\delta^{18} \mathrm{O}$ of Piceoxylon cellulose. Several methods of temperature estimation in the literature were used, including mechanistic models (Roden et al., 2000; Anderson et al., 2002) and transfer functions (Csank et al., 2013; Richter et al., 2008b; Ballantyne et al., 2006) that predict $\delta^{18} \mathrm{O}_{\mathrm{sw}}$ from $\delta^{18} \mathrm{O}_{\text {cellulose. MAT was derived }}$ from $\delta^{18} \mathrm{O}_{\text {sw }}$ using a $\delta^{18} \mathrm{O}_{\text {sw }}$ - temperature relationship developed for the Eocene (Fricke and Wing, 2004). Shown are references for model/function, relative humidity level (for mechanistic models), range (min-max) of MAT $\left({ }^{\circ} \mathrm{C}\right)$, and mean (standard deviation) of MAT $\left({ }^{\circ} \mathrm{C}\right)$ in chronology.

\begin{tabular}{lrrr}
\hline Reference & $\begin{array}{r}\text { Relative } \\
\text { Humidity }\end{array}$ & $\begin{array}{r}\text { Range MAT } \\
\left({ }^{\circ} \mathrm{C}\right)\end{array}$ & $\begin{array}{r}\text { Mean }(\sigma) \\
\text { MAT }\left({ }^{\circ} \mathrm{C}\right)\end{array}$ \\
\hline Mechanistic Models & & & \\
Roden et al. (2000) & $64 \%$ & $1-12.6$ & $5.9(2.3)$ \\
& $77 \%$ & $4.6-17.4$ & $10.0(2.6)$ \\
& $83 \%$ & $6.1-19.5$ & $11.7(2.7)$ \\
Anderson et al. (2002) & $64 \%$ & $10.6-16.3$ & $13.1(1.2)$ \\
& $77 \%$ & $13.3-19.5$ & $16.0(1.3)$ \\
& $83 \%$ & $15.3-21.9$ & $18.2(1.3)$ \\
\hline Transfer Functions & & & \\
Csank et al. (2013) & & $6.5-15.4$ & $10.3(1.8)$ \\
Richter et al. (2008b) & & $2.4-10.5$ & $5.9(1.7)$ \\
Ballantyne et al. (2006) & & $7.7-16.4$ & $11.9(1.8)$ \\
\hline Mean of all methods & & $7.5-16.6$ & $11.4(1.8)$ \\
\hline
\end{tabular}

study, mean $( \pm \sigma) \delta^{13} \mathrm{C}_{\mathrm{atm}}$ estimates were $-4.8( \pm 0.7) \%$, $-6.3( \pm 0.6) \%$, and $-5.5( \pm 0.7) \%$ using Eqs. (7), (8), and (9) respectively, based on mean $( \pm \sigma) \delta^{13} \mathrm{C}_{\text {cellulose of }}$ $-20.8( \pm 0.8) \%$. This $\delta^{13} \mathrm{C}_{\text {atm }}$ range matches the $90 \%$ confidence interval of $\delta^{13} C_{\text {atm }}$ by Tipple et al. (2010) for the early Eocene (mean $\delta^{13} C_{\text {atm }}=-5.7 \%$; $90 \%$ confidence interval: -4.8 to $-6.3 \%$ ) based on isotopes of benthic foraminifera (Table 3). Solving for $\Delta$ in Eq. (6) gives $19.4 \%$ (from $\delta^{13} \mathrm{C}_{\mathrm{atm}}$ of Eq. 7), $17.9 \%$ (from $\delta^{13} \mathrm{C}_{\mathrm{atm}}$ of Eq. 8), and $18.7 \%$ (from $\delta^{13} \mathrm{C}_{\text {atm }}$ of Eq. 9). Based on these $\Delta$ values, the $c_{\mathrm{i}} / c_{\mathrm{a}}$ would be $0.66,0.60$, and 0.63 , respectively. Assuming an early Eocene $p \mathrm{CO}_{2}$ of $915 \mathrm{ppmV}$ (Schubert and Jahren, 2013), these $c_{\mathrm{i}} / c_{\mathrm{a}}$ values lead to intrinsic water use efficiency (iWUE) estimates of 192, 229, and $211 \mu \mathrm{mol} \mathrm{mol}^{-1}$, respectively (Eq. 10; Table 3 ). In modern climates, $c_{\mathrm{i}} / c_{\mathrm{a}}$ may range from as low as 0.45 in Picea crassifolia Kom. growing in arid regions (Liu et al., 2007) to $c_{\mathrm{i}} / c_{\mathrm{a}}$ values as high as 0.6 for Picea glauca (Moench) Voss. (Freeden and Sage, 1999) and 0.66 for Picea abies (L.) Karst (Wallin and Skärby, 1992) in greenhouse-grown Pinus sylvestris trees at ambient and increased $p \mathrm{CO}_{2}$ and temperature (Beerling, 1997). These results suggest that the high $p \mathrm{CO}_{2}$, high temperature conditions in the early Eocene subarctic, $c_{\mathrm{i}} / c_{\mathrm{a}}$ values were similar to modern.

Saurer et al. (2004) proposed three possible scenarios regarding the behavior of plant fractionation $(\Delta)$ with increasing atmospheric $p \mathrm{CO}_{2}\left(c_{\mathrm{a}}\right)$ : Scenario (1) leaf intercellular

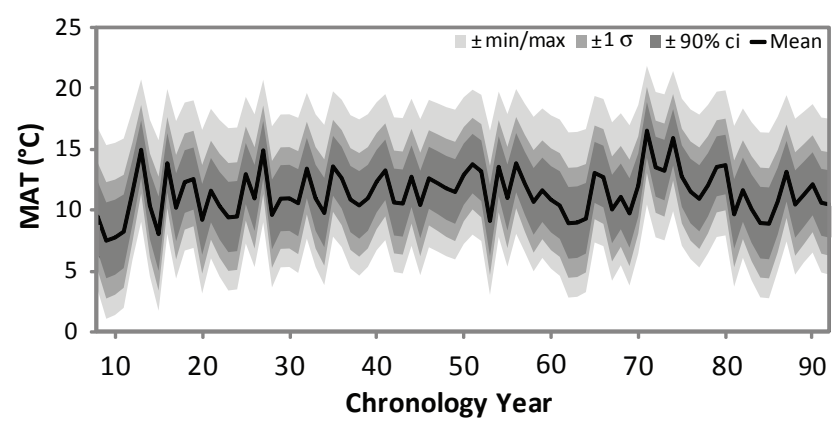

Figure 5. Mean annual temperature $\left(\mathrm{MAT}^{\circ} \mathrm{C}\right)$ based on all $\delta^{18} \mathrm{O}$ temperature reconstructions. Mean of all reconstructions (black line) is bracketed by $90 \%$ confidence interval ( $\pm 90 \%$ ci, dark gray fill), one standard deviation ( $\pm 1 \sigma$, medium gray fill), and minimum/maximum ( $\pm \mathrm{min} / \mathrm{max}$, light gray fill) estimates.

$p \mathrm{CO}_{2}\left(c_{\mathrm{i}}\right)$ remains constant with rising $c_{\mathrm{a}}$, thus $c_{\mathrm{i}} / c_{\mathrm{a}}$ decreases and internal water use efficiency (iWUE) increases strongly; Scenario (2) $c_{\mathrm{i}}$ increases proportionally to $c_{\mathrm{a}}$, causing $c_{\mathrm{i}} / c_{\mathrm{a}}$ to remain relatively constant and iWUE to increase; Scenario (3) $c_{\mathrm{i}}$ increases at about the same rate as $c_{\mathrm{a}}$, and $c_{\mathrm{i}} / c_{\mathrm{a}}$ increases while iWUE remains constant. In free air carbon enrichment (FACE) plots, $c_{\mathrm{i}} / c_{\mathrm{a}}$ tends to decrease slightly ( -0.02 to $-0.08 \%$ ), but significantly, in high $p \mathrm{CO}_{2}$ $(\sim 600 \mathrm{ppmV})$ with respect to control plots $(\sim 400 \mathrm{ppmV})$, supporting Scenario (1) above (Battipaglia et al., 2013). However, the opposite pattern is found in controlled growth chamber experiments (Lomax et al., 2012; Schubert and Jahren, 2012). Using strict controls over hydrologic variables (i.e., relative humidity, soil water potential), Schubert and Jahren (2012) found that $\Delta$ is positively related to $p \mathrm{CO}_{2}$ by a hyperbolic function, such that $\Delta$ does not increase infinitely with increasing $p \mathrm{CO}_{2}$ as with a linear function, but flattens out as it approaches a limit of $28.26 \%$. This increase in $\Delta$ may increase active carboxylation sites on RuBisCo, thus increasing $c_{\mathrm{i}} / c_{\mathrm{a}}$, which would support Scenario (3) (Schubert and Jahren, 2012). However, these growth-chamber experiments were designed to identify the relationship between $\Delta$ and $p \mathrm{CO}_{2}$ at a constant stomatal density $(\mathrm{SD}=$ number of stomata per unit area on the leaf). During the Eocene SD was lower than modern SD in response to higher $p \mathrm{CO}_{2}$, which would have affected gas exchange and water use efficiency (Beerling et al., 2009).

Stomatal density or stomatal index (SI) of fossil leaves have long been used as paleo- $p \mathrm{CO}_{2}$ proxies based on the observation that plants decrease SD and SI in high $p \mathrm{CO}_{2}$ (Beerling et al., 1998) and vice versa (Woodward, 1986, 1987) following a negative hyperbolic relationship that flattens out at high $p \mathrm{CO}_{2}$ levels (Royer, 2003; Beerling et al., 2009), mirroring the hyperbolic relationship between $\Delta$ and $p \mathrm{CO}_{2}$ (Schubert and Jahren, 2012). SD and SI display remarkable phenotypic and genotypic plasticity to changing atmospheric $p \mathrm{CO}_{2}$ over both short-term (i.e., hours to months) and long- 
Table 3. Early Eocene $\delta^{13} \mathrm{C}_{\mathrm{atm}}, \Delta, c_{\mathrm{i}} / c_{\mathrm{a}}$, and intrinsic water use efficiency (iWUE) estimates. $\delta^{13} \mathrm{C}_{\mathrm{atm}}(\%$ o) results of Tipple et al. (2010; mean and $90 \%$ confidence interval bounds), are compared with results from this study: equation used to calculate $\delta^{13} \mathrm{C}_{\mathrm{atm}}(\%)$, along with estimates of $\Delta(\%), c_{\mathrm{i}} / c_{\mathrm{a}}(\%)$, and iWUE $\left(\mu \mathrm{mol} \mathrm{mol}{ }^{-1}\right)$. Average early Eocene $p \mathrm{CO}_{2}$ of $915 \mathrm{ppmV}$ was used (Schubert and Jahren, 2013).

\begin{tabular}{lr|rrrrr}
\hline \multicolumn{2}{c|}{ Tipple et al. (2010) } & \multicolumn{5}{c}{ This Study } \\
\hline Bounds & $\delta^{13} \mathrm{C}_{\mathrm{atm}}$ & Equation & $\delta^{13} \mathrm{C}_{\mathrm{atm}}$ & $\Delta$ & $c_{\mathrm{i}} / c_{\mathrm{a}}$ & iWUE \\
\hline Lower 90\% & -4.8 & Eq. (7) & -4.8 & 19.4 & 0.66 & 192 \\
Upper 90\% & -6.3 & Eq. (8) & -6.3 & 17.9 & 0.60 & 229 \\
Mean & -5.7 & Eq. (9) & -5.5 & 18.7 & 0.63 & 211 \\
\hline
\end{tabular}

term (i.e., evolutionary) timescales (Beerling and Chaloner, 1993). Reducing SD/SI during high $p \mathrm{CO}_{2}$ maximizes efficiency in $\mathrm{CO}_{2}$ uptake by leaf stomata, while minimizing water loss, thus resulting in iWUE over twice as much as modern iWUE in high-latitude Pinus trees $<100 \mu \mathrm{mol} \mathrm{mol}^{-1}$; Gagen et al., 2011). Greenhouse experiments with Pinus sylvestris $\mathrm{L}$. trees at elevated $p \mathrm{CO}_{2}(560 \mathrm{ppmV})$ and temperature $\left(+3\right.$ to $\left.5^{\circ} \mathrm{C}\right)$ show no change in $c_{\mathrm{i}} / c_{\mathrm{a}}$ despite reduced SD and increased iWUE (Beerling, 1997). Moreover, manipulations of SD via epidermal patterning factor (EPF) genes in Arabidopsis mutants suggest that reduced (increased) SD may lead to decreased (increased) transpiration and stomatal conductance $\left(g_{\mathrm{s}}\right)$, along with increased (decreased) growth and iWUE (Doheny-Adams et al., 2012). Lower SD causes reductions in $c_{\mathrm{i}} / c_{\mathrm{a}}$, which increases iWUE without changing photosynthetic capacity (Franks et al., 2015). This optimizes operational stomatal conductance $\left(g_{\text {sop }}\right)$ around a "sweet spot" of $20 \%$ maximum anatomical conductance $\left(g_{\mathrm{smax}}\right)$ (Dow et al., 2014). By operating at around $20 \%$ of $g_{\text {smax }}$, stomatal guard cells can be more responsive to rapid environmental changes in RH or VPD. Therefore, the opposing hyperbolic curves ( $\Delta$ vs. $p \mathrm{CO}_{2}, \mathrm{SD}$ vs. $p \mathrm{CO}_{2}$ ) may balance out as a result of this phenotypic and genotypic plasticity, stabilizing $\Delta$ and $c_{\mathrm{i}} / c_{\mathrm{a}}$ through geologic time (Ehleringer and Cerling, 1995; Dawson et al., 2002), supporting Scenario (2) above (Saurer et al., 2004).

In the modern climate, the Suess effect greatly alters $\delta^{13} \mathrm{C}_{\mathrm{atm}}$, curving it unnaturally downward starting with the industrial revolution, so tree ring records spanning this period must be isotopically corrected (McCarroll et al., 2009). However, in the early Eocene average $\delta^{13} \mathrm{C}_{\text {atm }}$ levels were likely to be constant over the life of a tree in the absence of a hyperthermal event (Zachos et al., 2001). Therefore, any shifts upward or downward around the mean $\delta^{13} \mathrm{C}_{\text {cellulose }}$ are probably related to annual or seasonal changes in photosynthetic rate $(A)$ or stomatal conductance $\left(g_{\mathrm{s}}\right)$, both of which influence $c_{\mathrm{i}} / c_{\mathrm{a}}$. Photosynthesis would not have affected by high $p \mathrm{CO}_{2}$ under the continuous light of the polar summer (Beerling and Osborne, 2002), but may have been affected by cloud-related reductions in sunlight (Young et al., 2010).
We assume our $\delta^{13} \mathrm{C}_{\text {cellulose }}$ record to be a qualitative proxy of sunlight/cloudiness, with the exception of a brief period during the juvenile phase when trees must compete for light in the shaded understory, leading to a juvenile effect in the early part of some $\delta^{13} \mathrm{C}$ records (Gagen et al., 2007).

\subsubsection{Dual-isotope analysis}

Although precise quantitative estimates of sunlight cannot be made, analysis of both isotopes simultaneously can aid in qualitative assessment of solar variability. When both isotope data sets are normalized (Fig. 6, top graph) and summed (Fig. 6, middle graph), a signal related to RH and vapor pressure deficit (VPD) should be amplified, because both isotopes are affected by stomatal conductance $\left(g_{\mathrm{s}}\right)$ [low RH (high VPD) causes an increase in both $\delta^{18} \mathrm{O}_{\text {cellulose and }}$ $\delta^{13} \mathrm{C}_{\text {cellulose }}$, leading to a positive correlation (Saurer et al., 1995)]. Conversely, when the dual isotope data are normalized and subtracted, the remaining unexplained variance relating to factors other than RH should be amplified (Fig. 6, bottom graph). For $\delta^{18} \mathrm{O}_{\text {cellulose, }}, \delta^{18} \mathrm{O}_{\mathrm{sw}}$ is a major factor (related to temperature of precipitation and precipitation sources), and for $\delta^{13} \mathrm{C}_{\text {cellulose }}$ cloudiness is the most likely controlling factor because clouds limit photosynthetic rate. Modern trees growing near the Arctic Circle in Fennoscandia show high correlations between annual records of stable carbon isotope ratios $\left(\delta^{13} \mathrm{C}\right)$ and records of cloud cover, where the dominant factor in their $\delta^{13} \mathrm{C}$ records is photosynthetic rate (Young et al., 2010, 2012). When more sunlight is received, photosynthetic rate is increased, which reduces isotopic discrimination and raises the $\delta^{13} \mathrm{C}$ value. However, a converse relationship exists between sunlight and temperature at different timescales. Proxy records suggest that at high frequency (annual) timescales, sunlight and temperature are positively related (i.e., sunny $=$ warm, cloudy $=$ cool), but at low frequencies (multidecadal), they are negatively related (i.e., cloudy $=$ warm, sunny $=$ cool; Young et al., 2012). This is somewhat counterintuitive but sustained, regional warmer temperatures cause an increase in evaporation and cloud cover, bringing latent heat to northern latitudes through increased precipitation. Simultaneously, clouds cause shortterm local cooling by blocking solar radiation.

Spectral analysis of the normalized summed data $\left(\Sigma_{Z \text {-score }}\right)$ shows a significant interannual-scale pattern (23 ypc; Fig. 6, middle graph), whereas the normalized subtracted data $\left(\Delta_{Z \text {-score }}\right)$ show multidecadal cyclicity $(20$ $30 \mathrm{ypc}$; Fig. 6, bottom graph). This pattern is similar to modes of the modern Pacific Decadal Oscillation (PDO) and Arctic Oscillation/North Atlantic Oscillation (AO/NAO), which operate on multidecadal timescales (Mantua et al., 1997; Young et al., 2012). These modes are also teleconnected with ENSO cycles (2-7 ypc) in the modern climate (Gershunov and Barnett, 1998). Temperature increases during positive phases of the PDO contribute to greater evaporation, leading to enhanced cloud formation and precipitation 


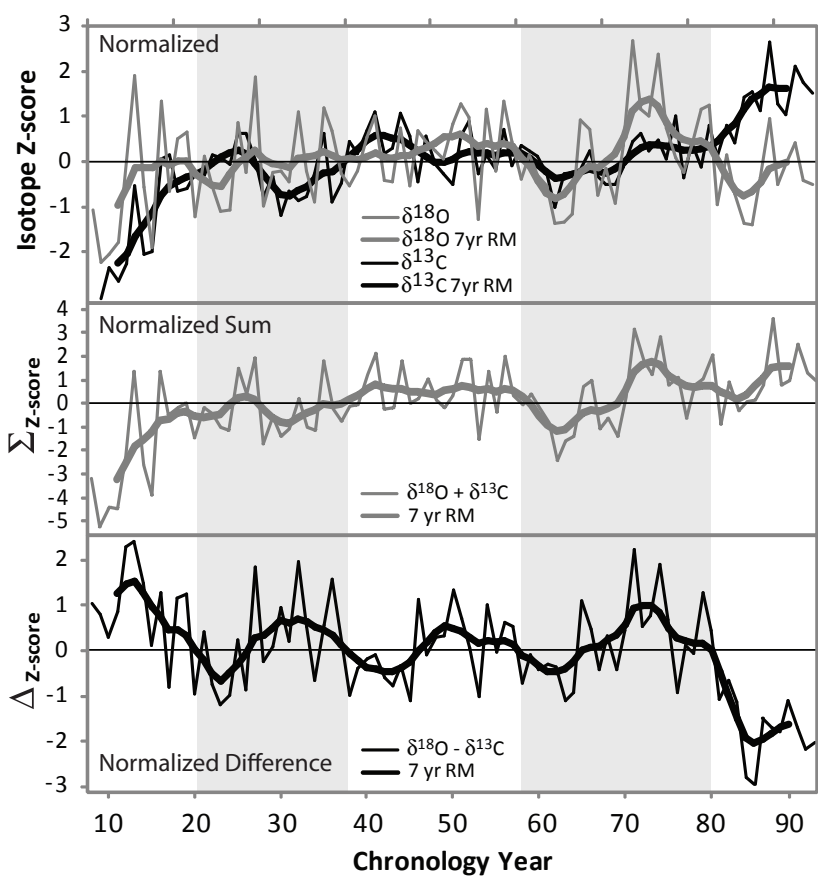

Figure 6. Results of dual-isotope $\left(\delta^{18} \mathrm{O}\right.$ and $\left.\delta^{13} \mathrm{C}\right)$ analysis $(n=86)$. Upper panel: normalized $\delta^{18} \mathrm{O}\left(\delta^{18} \mathrm{O}_{\mathrm{Z} \text {-score, thin gray }}\right.$ line) and $\delta^{13} \mathrm{C}\left(\delta^{13} \mathrm{C}_{\mathrm{Z} \text {-score }}\right.$ thin black line), and 7-year triangu-

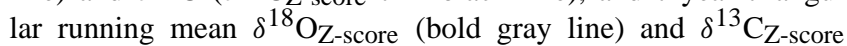

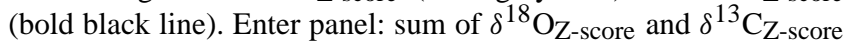

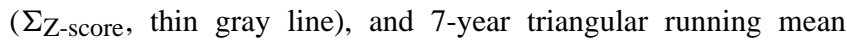
(bold gray line). Lower panel: difference of $\delta^{18} \mathrm{O}_{\mathrm{Z} \text {-score }}$ minus $\delta^{13} \mathrm{C}_{\mathrm{Z} \text {-score }}\left(\Delta_{\mathrm{Z} \text {-score }}\right.$, thin black line), and 7-year triangular running mean (bold black line). Shaded regions in upper and lower panels highlight the bidecadal oscillations evident in the $\Delta_{Z \text {-score }}$ chronology in the lower panel.

levels on a strongly bidecadal mode (Chiacchio et al., 2010). Sparse cloud cover may not significantly block sunlight, as diffusion may redistribute it through the canopy (Reinhardt et al., 2010; Urban et al., 2012). However, if cloud cover is very dense it may limit tree growth by blocking photons necessary for photosynthesis (Ritchie, 2010). Heavy cloud cover has been implicated in reduced photosynthetic rate of modern black spruce (Picea mariana (Mill.) Britton, Sterns \& Poggenburg) growing at subarctic treeline in Quebec, Canada (Vowinckel et al., 1975).

When dual-isotope analyses $\left(\Sigma_{Z \text {-score }}\right.$ and $\left.\Delta_{Z \text {-score }}\right)$ were compared with RWI data, an apparent positive association existed between $\Delta_{\text {Z-score }}$ and RWI at low frequencies. The middle portion (i.e., tree rings least likely affected by juvenile growth or diagenetic factors) of the 7-year running mean data was strongly positively correlated (TR 34-89; $R=0.68, p<0.0001, n=55$; Fig. 7). This suggests that multidecadal climate fluctuations of temperature and precipitation led to decades of increased tree growth during positive phases of the PDO-like pattern, and decades of decreased growth during negative phases. No association was found between $\Sigma_{Z \text {-score }}$ and RWI records. If $\Sigma_{Z \text {-score }}$ is related to Eocene RH, sustained high humidity with low variability may explain this non-association (Saurer et al., 1995).

In the early Eocene, subarctic trees may have been strongly dependent on both light and precipitation, and therefore influenced by cloud coverage. Sewall and Sloan (2001) hypothesized that in the Eocene, the lack of polar ice contributed to a stable positive Arctic Oscillation, rather than the multidecadal dipole that currently exists. However, the RWI and isotope data presented here suggest that PDO-like cyclicity operated in the early Eocene, possibly contributing to AO teleconnections as it does today (Jia et al., 2009). Oceanic Rossby waves may have set the timescale for multidecadal shifts in the position of the Aleutian low-pressure system, which changes the trajectory of weather patterns (Gershunov and Barnett, 1998). During positive PDO phases the position of the Aleutian low shifts southward, drawing in ENSOmediated tropical moisture and delivering it to the Subarctic (Fig. 8). Another possibility for the $\delta^{18} \mathrm{O}$ variation is multidecadal shifts in source water location (e.g., Pacific Ocean, Arctic Ocean). In the early Eocene the Arctic Ocean was isolated from other oceans, with high freshwater content from high precipitation (Brinkhuis et al., 2006). Thus, the Arctic Ocean source water would have been depleted in $\delta^{18} \mathrm{O}$ relative to Pacific Ocean source water. Therefore, the trees in our study may have alternately received low- $\delta^{18} \mathrm{O}$ from the Arctic, and high- $\delta^{18} \mathrm{O}$ from the Pacific shifting every 20 30 years.

Jahren and Sternberg (2002) suggested that meridional transport of precipitation northward across the North American continent could have depleted the $\delta^{18} \mathrm{O}$ of rainwater before reaching their study site. However, such a strong southerly wind current system seems unlikely in the Eocene, if the latitudinal temperature gradient was low (Greenwood and Wing, 1995), and given similar orbital variability (Laskar et al., 2011). However, if Eocene equatorial temperatures were high $\left(35-40^{\circ} \mathrm{C}\right.$, Caballero and Huber, 2010) temperature gradients may have been stronger than previously thought, leading to strong winds. Another possible explanation for the low $\delta^{18} \mathrm{O}$ values of extreme northern polar forests in that study is that the source water was largely recycled from depleted Arctic Ocean sources, or water transpired from trees (Jasechko et al., 2013). Additionally, mineral contamination (e.g., by iron oxides) may also cause negative $\delta^{18} \mathrm{O}$ errors (Richter et al., 2008a). Paleoclimate models suggest that increases in atmospheric water vapor due to an ice-free Arctic may have created conditions conducive to formation of a stable Arctic cyclone, through which southern precipitation sources could not penetrate (Sewall and Sloan, 2001). Our results suggest that if this stable Arctic cyclone existed then it probably still had teleconnections with a PDO-like mechanism, causing the edge of the cyclone to shift northward and southward on multidecadal timescales. 


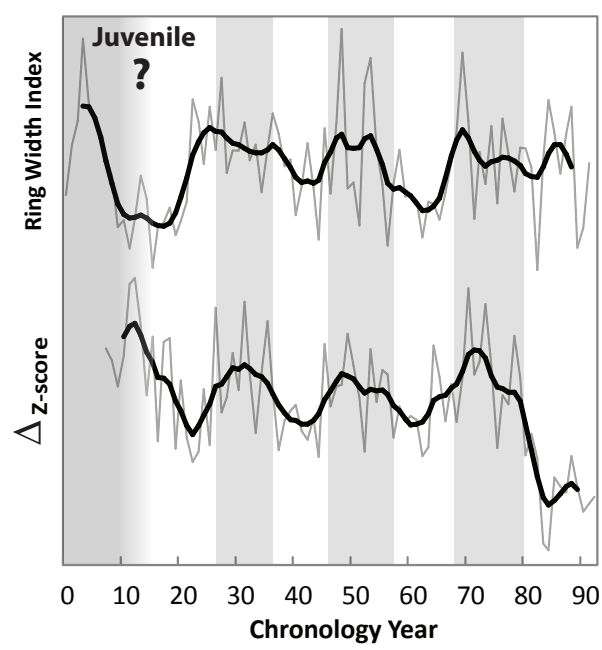

Figure 7. Correspondence of Piceoxylon tree-ring width indices (RWI) and stable isotope chronologies. (Upper) Piceoxylon RWI ( $n=92$, gray line) with 7-year triangular running mean (bold black line) to highlight low-frequency variability. (Lower) Piceoxylon isotope $\Delta_{Z}$-score chronology ( $n=86$, gray line) with 7-year triangular running mean (bold black line) to highlight low-frequency variability. Here, gray boxes denote warmer and cloudier decades with above average tree ring growth. The first seven tree rings of the RWI record were not analyzed for stable isotopes, due to concerns about possible influences of juvenile tree growth on the isotope record. Question mark at the beginning of the TR record depicts uncertainty due to a possible juvenile growth signal.

\section{Conclusions}

Multiple tree-ring based proxies were examined to study the climate of the early Eocene. The material used was extremely well-preserved Piceoxylon Gothan 1905 mummified wood found in kimberlite diamond mines (ca. 53.3 Ma), which allowed geochemical investigations of primordial cellulose. Stable isotope data $\left(\delta^{18} \mathrm{O}\right.$ and $\left.\delta^{13} \mathrm{C}\right)$ were collected from subannually and annually sampled increments along tree-ring chronologies. Mean annual temperatures (MAT) were estimated to be $11.4^{\circ} \mathrm{C}$ using $\delta^{18} \mathrm{O}$ isotopes, taking the mean of a variety of commonly used mechanistic models (Roden et al., 2000; Anderson et al., 2002) and transfer functions (Ballantyne et al., 2006; Richter et al., 2008b; Csank et al., 2013) designed for estimating temperature with wood cellulose. This value is in agreement with other studies using alternate proxies (Greenwood and Wing, 1995; Sunderlin et al., 2011). The range is $7.5-16.6{ }^{\circ} \mathrm{C}$, which is a $9{ }^{\circ} \mathrm{C}$ difference from warmest to coolest MAT. Seasonal climates were also investigated: mean annual range of temperature was $3.5-16.4^{\circ} \mathrm{C}(n=4)$, with a mean of $10.9^{\circ} \mathrm{C}\left(1 \sigma=3.0^{\circ} \mathrm{C}\right)$. Warm month mean temperatures were $\sim 16.4 \pm 3.0^{\circ} \mathrm{C}$, but cold month mean temperatures could not be calculated with this archive, as the trees were dormant during winter when continuous darkness persisted. Our average estimate of $\delta^{13} \mathrm{C}$

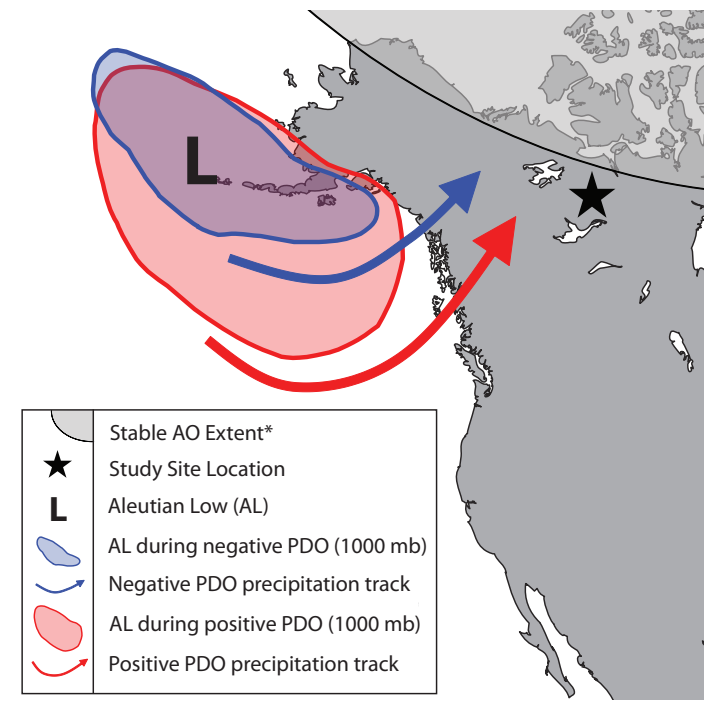

Figure 8. Position and strength of Aleutian low-pressure system during positive and negative phases of the PDO in relation to study site. Hypothesized stable Arctic Oscillation during the Eocene depicted by gray arc in upper right corner (see Sewall and Sloan 2001). $1000 \mathrm{mb}$ sea level pressure (SLP) contours shown for negative PDO (blue shaded area) and positive PDO (red shaded area). Weather patterns are altered according to these changes in SLP (blue arrow - negative PDO, red arrow - positive PDO), thus altering the distribution of precipitation across North America. Positions of 1000 mb contours of Aleutian low after NOAA-CIRES/Climate Diagnostics Center (Jan-Mar sea level pressure $(\mathrm{mb})$ composite for negative PDO 1988, 1999; for positive PDO 1983, 1987, 1992, 1998).

of Eocene atmosphere $(-5.5 \pm 0.7 \%$ ) based on transfer functions (Arens et al., 2000; Lomax et al., 2012) was in agreement with the estimate of Tipple et al. (2010) for ca. 53.3 Ma, who used independent proxy methods (i.e., benthic foraminifera). Average estimates of $\delta^{13} \mathrm{C}$ discrimination $(\Delta=18.7 \pm 0.8 \%$ ) , and the ratio of leaf intercellular to atmospheric $p \mathrm{CO}_{2}\left(c_{\mathrm{i}} / c_{\mathrm{a}}=0.63 \pm 0.03 \%\right)$, were similar to those found in modern trees in ambient or elevated $p \mathrm{CO}_{2}$ (Greenwood, 1997), supporting the hypothesis that $c_{\mathrm{i}} / c_{\mathrm{a}}$ is stable through geologic time (Ehleringer and Cerling, 1995). Tree leaf stomatal density is reduced in high $p \mathrm{CO}_{2}$, environments, causing intrinsic water use efficiency (iWUE) to be over twice as high as in modern trees. Assuming an early Eocene $p \mathrm{CO}_{2}$ of $915 \mathrm{ppmV}$ (Schubert and Jahren, 2013), iWUE $=211 \pm 20 \mu \mathrm{mol} \mathrm{mol}^{-1}$, which would explain the high levels of forest productivity observed in early Eocene polar forests (Williams, 2007). Dual-isotope analysis suggests that a strong interannual ( $2-3 \mathrm{ypc})$ signal related to stomatal functioning influenced both isotopes, as they are positively correlated $\left(\Sigma_{Z \text {-score }}\right)$. However, if the first 4-8 tree rings representing juvenile growth are removed, the dual-isotopes are not correlated, suggesting that factors other than stomatal functioning are more important $\left(\Delta_{Z \text {-score }}\right)$. Therefore, the most likely explanation for these patterns is 
that the dominant signal is related to multidecadal climate variability (e.g., Pacific Decadal Oscillation, PDO) responsible for low-frequency shifts in $\delta^{18} \mathrm{O}$ of source water, and $\delta^{13} \mathrm{C}$ shifts related to cloudiness regimes on bidecadal (20$30 \mathrm{ypc})$ timescales.

\section{The Supplement related to this article is available online at doi:10.5194/bg-12-5899-2015-supplement.}

Author contributions. B. A. Hook designed study, collected and analyzed data, wrote manuscript, J. Halfar edited manuscript, Z. Gedalof edited manuscript, J. Bollmann edited manuscript, D. J. Schulze edited manuscript.

Acknowledgements. Funding was provided by J. Halfar at the University of Toronto Mississauga through a National Sciences and Engineering Research Council of Canada Discovery Grant. We thank Ekati Diamond Mine, and Diavik Diamond Mine (jointly owned by Dominion Diamond Corporation and Rio Tinto Group, when Panda Pipe samples were donated, Ekati Diamond Mine was owned by BHP Billiton), for access to sample materials; U. Fekl and U. Wortmann for access to equipment; R. E. Plummer, K. J. Steele and M. N. Evans at the University of Maryland Stable Isotope laboratory for conducting mass spectrometry. J. Basinger for helpful editing suggestions.

Edited by: X. Wang

\section{References}

Alton, P. B.: Reduced carbon sequestration in terrestrial ecosystems under overcast skies compared to clear skies, Agr. Forest Meteorol., 148, 1641-1653, 2008.

Anderson, W. T., Bernasconi, S. M., McKenzie, J. A., Saurer, M., and Schweingruber, H. F.: Model evaluation for reconstructing the oxygen isotopic composition in precipitation from tree ring cellulose over the last century, Chem. Geol., 182, 121-137, 2002.

Arens, N. C., Jahren, A. H., and Amundson, R.: Can $\mathrm{C}_{3}$ plants faithfully record the carbon isotopic composition of atmospheric carbon dioxide? Paleobiology, 26, 137-164, 2000.

Ballantyne, A. P., Rybczynski, N., Baker, P. A., Harington, C. R., and White, D.: Pliocene Arctic temperature contraints from the growth rings and isotopic composition of fossil larch, Palaeogeogr. Palaeocl., 242, 188-200, 2006.

Barbour, M. M., Andrews, T. J., and Farquhar, G. D.: Correlations between oxygen isotope ratios of wood constituents of Quercus and Pinus samples from around the world, Aust. J. Plant. Physiol., 28, 335-348, 2001.

Barbour, M. M., Walcroft, A. S., and Farquhar, G. D.: Seasonal variation in $\delta^{13} \mathrm{C}$ and $\delta^{18} \mathrm{O}$ of cellulose from growth rings of Pinus radiata, Plant. Cell Environ., 25, 1483-1499, 2002.
Beerling, D. L.: Carbon isotope discrimination and stomatal responses of mature Pinus sylvestris L. trees exposed in situ for three years to elevated $\mathrm{CO}_{2}$ and temperature, Acta Ecol., 18, 697-712, 1997.

Beerling, D. J. and Chaloner, W. G.: Evolutionary responses of stomatal density to global $\mathrm{CO}_{2}$ change, Biol. J. Linn. Soc., 48, 343-353, 1993.

Beerling, D. J. and Franks, P. J.: The hidden cost of transpiration, Nature, 464, 495-496, 2010.

Beerling, D. J. and Osborne, C. P.: Physiological Ecology of Mesozoic Polar Forests in a High $\mathrm{CO}_{2}$ Environment, Ann. Bot., 89, 329-339, 2002.

Beerling, D. J., McElwain, J. C., and Osborne, C. P.: Stomatal responses of the 'living fossil' Ginkgo biloba L. to changes in atmospheric $\mathrm{CO}_{2}$ concentrations, J. Ex. Bot., 49, 1603-1607, 1998.

Beerling, D. J., Fox, A., and Anderson, C. W.: Quantitative uncertainty analyses of ancient atmospheric $\mathrm{CO}_{2}$ estimates from fossil leaves, Am. J. Sci., 309, 775-787, 2009

Bowen, G. J.: Isoscapes: Spatial pattern in isotopic biogeochemistry, Annu. Rev. Earth. Pl. Sci., 38, 161-187, 2010.

Bowen, G. J. and Revenaugh, J.: Interpolating the isotopic composition of modern meteoric precipitation, Water Resour Res., 39, 1299, doi:10.1029/2003WR002086, 2003.

Brendel, O., Ianetta, P. P. M., and Stewart, D.: A rapid and simple method to isolate pure alpha-cellulose, Phytochem. Analysis, 11, 7-10, 2000.

Brinkhuis, H., Schouten, S., Collinson, M. E., Sluijs, A., Sinninghe Damsté, J. S., Dickens, G. R., Huber, M., Cronin, T. M., Onodera, J., Takahashi, K., Bujak, J. P., Stein, R., van der Burgh, J., Eldrett, J. S., Harding, I. C., Lotter, A. F., Sangiorgi, F., van Konijnenburg-van Cittert, H., de Leeuw, J. W., Mattheissen, J., Backman, J., Moran, K., Clemens, S., Eynaud, F., Gattacceca, J., Jakobsson, M., Jordan, R., Kaminski, M., King, J., Koc, N., Martinez, N.C., McInroy, D., Moore, Jr., T. C., O’Regan, M., Pälike, H., Rea, B., Rio, D., Sakamoto, T., Smith, D. C., St John, K. E. K., Suto, I., Suzuki, N., Watanabe, M., and Yamamoto, M.: Episodic fresh surface waters in the Eocene Arctic Ocean, Nature, 441, 606-609, 2006.

Bunn, A. G.: A dendrochronology program library in R (dplR), Dendrochronologia, 26, 115-124, 2008.

Bunn, A. G.: Statistical and visual crossdating in R using the dplR library, Dendrochronologia, 28, 251-258, 2010.

Caballero, R. and Huber, M.: Spontaneous transition to superrotation in warm climates simulated by CAM3, Geophys. Res. Lett., 37, L11701, doi:10.1029/2010GL043468, 2010.

Chiacchio, M., Ewen, T., Wild, M., and Arabini, E.: Influence of climate shifts on decadal variations of surface solar radiation in Alaska, J. Geophys. Res., 115, D00D21, doi:10.1029/2009JD012533, 2010.

Creaser, R. A., Grütter, H., Carlson, J., and Crawford, B.: Macrocrystal phlogopite $\mathrm{Rb}-\mathrm{Sr}$ dates for the Ekati property kimberlites, Slave Province, Canada: Evidence for multiple intrusive episodes in the Paleocene and Eocene, Lithos, 76, 399-414, 2004.

Csank, A. Z., Fortier, D., and Leavitt, S. W.: Annually resolved temperature reconstructions from a late Pliocene-early Pleistocene polar forest on Bylot Island, Canada, Palaeogeogr. Palaeocl., 369, 313-322, 2013. 
Dansgaard, W.: Stable isotopes in precipitation, Tellus, 16, 368436, 1964.

Daux, V., Edouard, J. L., Masson-Delmotte, V., Stievenard, M., Hoffmann, G., Pierre, M., Mestre, O., Danis, P. A., and Guibal, F.: Can climate variations be inferred from tree-ring parameters and stable isotopes from Larix decidua? Juvenile effects, budmoth outbreaks, and divergence issue, Earth Planet Sci. Lett., 309, 221-233, 2011.

Dawson, T. E., Mambelli, S., Plamboeck, A. H., Templer, P. H., and Tu, K. P.: Stable isotopes in plant ecology, Ann. Rev. Ecol. Syst., 33, 507-559, 2002.

DeNiro, M. J. and Epstein, S.: Relationship between the oxygen isotope ratios of terrestrial plant cellulose, carbon dioxide, and water, Science, 204, 51-53, 1979.

Doheny-Adams, T., Hunt, L., Franks, P. J., Beerling, D. J., and Gray, J. E.: Genetic manipulation of stomatal density influences stomatal size, plant growth and tolerance to restricted water supply across a growth carbon dioxide gradient, Philos. T. R. Soc. B, 367, 547-555, 2012.

Dow, G. J., Bergmann, D. C., and Berry, J. A.: An integrated model of stomatal development and leaf physiology, New. Phytol., 201, 1218-1226, 2014.

Eberle, J. J., Fricke, H. C., Humphrey, J. D., Hackett, L., Newbrey, M. G., and Hutchison, J. H.: Seasonal variability in Arctic temperatures during early Eocene time, Earth Planet Sci. Lett., 296, 481-486, 2010.

Ehleringer, J. R. and Cerling, T. E.: Atmospheric $\mathrm{CO}_{2}$ and the ratio of intercellular to ambient $\mathrm{CO}_{2}$ concentrations in plants, Tree Physiol., 15, 105-111, 1995.

Farquhar, G. D., O'Leary, M. H., and Berry, J. A.: On the relationship between carbon isotope discrimination and the intercellular carbon dioxide in leaves, Aust. J. Plant. Physiol., 9, 121-137, 1982.

Farquhar, G. D., Ehleringer, J. R., and Hubick, K. T.: Carbon isotope discrimination and photosynthesis, Annu. Rev. Plant. Phys., 40, 503-537, 1989.

Ferrio, J. P. and Voltas, J.: Carbon and oxygen isotope ratios in wood constituents of Pinus halepensis as indicators of precipitation, temperature and vapour pressure deficit, Tellus B, 57, 164-173, 2005.

Flanagan, L. B., Comstock, J. P., and Ehleringer, J. R.: Comparison of Modeled and Observed Environmental Influences on the Stable Oxygen and Hydrogen Isotope Composition of Leaf Water in Phaseolus vulgaris L., Plant Physiol., 96, 588-596, 1991.

Francis, J. E.: A 50-Million-Year-Old Fossil Forest from Strathcona Fiord, Ellesmere Island, Arctic Canada: Evidence for a Warm Polar Climate, Arctic, 41, 314-318, 1988.

Francis, J. E. and Poole, I.: Cretaceous and early Tertiary climates of Antarctica: evidence from fossil wood, Palaeogeogr. Palaeocl., 182, 47-64, 2002.

Franks, P. J., Doheny-Adams, T. W., Britton-Harper, Z. J., and Gray, J. E.: Increasing water-use efficiency directly through genetic manipulation of stomatal density, New. Phytol., 207, 188-195, 2015.

Freeden, A. L. and Sage, R. F.: Temperature and humidity effects on branchlet gas-exchange in white spruce: an explanation for the increase in transpiration with branchlet temperature, Trees, 14, 161-168, 1999.
Fricke, H. C. and O'Neil, J. R.: The correlation between ${ }^{18} \mathrm{O} /{ }^{16} \mathrm{O}$ ratios of meteoric water and surface temperature: its use in investigating terrestrial climate change over geologic time, Earth Planet Sci. Lett., 170, 181-196, 1999.

Fricke, H. C. and Wing, S. L.: Oxygen isotope and paleobotanical estimates of temperature and $\delta^{18} \mathrm{O}$-latitude gradients over North America during the early Eocene, Am. J. Sci., 304, 612-635, 2004.

Gagen, M., McCarroll, D., Loader, N. J., Robertson, I., Jalkanen, R., and Anchukaitis, K. J.: Exorcising the 'segment length curse': summer temperature reconstruction since AD 1640 using nondetrended stable carbon isotope ratios from pine trees in northern Finland, Holocene 17, 435-446, 2007.

Gagen, M., Finsinger, W., Wagner-Cremer, F., McCarroll, D., Loader, N. J., Robertson, I., Jalkanen, R., Young, G., and Kirchhefer, A.: Evidence of changing intrinsic water-use efficiency under rising atmospheric $\mathrm{CO}_{2}$ concentrations in Boreal Fennoscandia from subfossil leaves and tree ring $\delta^{13} \mathrm{C}$ ratios, Glob. Change Biol., 17, 1064-1072, 2011.

Gaudinski, J. B., Dawson, T. E., Quideau, S., Schuur, E. A. G., Roden, J. S., Trumbore, S. E., Sandquist, D. R., Oh, S.-W., and Wasylishen, R. E.: Comparative analysis of cellulose preparation techniques for use with ${ }^{13} \mathrm{C},{ }^{14} \mathrm{C}$, and ${ }^{18} \mathrm{O}$ isotopic measurements, Anal. Chem., 77, 7212-7224, 2005.

Gershunov, A. and Barnett, T. P.: Interdecadal modulation of ENSO teleconnections, B. Am. Meteorol. Soc., 79, 2715-2725, 1998.

Greenwood, D. R., and Wing, S. L.: Eocene continental climates and latitudinal temperature gradients, Geology, 23, 1044-1048, 1995.

Helliker, B. R. and Richter, S. L.: Subtropical to boreal convergence of tree-leaf temperatures, Nature, 454, 511-514, 2008.

Hook, B., Halfar, J., Gedalof, Z., and Bollmann, J.: Controlled breaking of mummified wood for use in paleoenvironmental analysis, Tree-Ring Res., 69, 87-92, 2013.

Hook, B., Halfar, J., Bollmann, J., Gedalof, Z., Rahman, M. A., Reyes, J., and Schulze, D. J.: Extraction of $\alpha$-cellulose from mummified wood for stable isotopic analysis, Chem. Geol., 405, 19-27, 2015.

Huber, M. and Caballero, R.: Eocene El Niño: Evidence for robust tropical dynamics in the "hothouse", Science, 299, 877-881, 2003.

Huber, M. and Caballero, R.: The early Eocene equable climate problem revisited, Clim. Past, 7, 603-633, doi:10.5194/cp-7603-2011, 2011.

Intergovernmental Panel on Climate Change (IPCC): Climate Change 2013: The Physical Science Basis, Contribution of Working Group I to the Fifth Assessment Report of the Intergovernmental Panel on Climate Change, edited by: Stocker, T. F., Qin, D., Plattner, G.-K., Tignor, M., Allen, S. K., Boschung, J., Nauels, A., Xia, Y., Bex, V., and Midgley, P. M., Cambridge University Press, Cambridge, United Kingdom and New York, NY, USA, 1535 pp., 2013.

Ivany, L. C., Brey, T., Huber, M., Buick, D. P., and Schöne, B. R.: El Niño in the Eocene greenhouse recorded by fossil bivalves and wood from Antarctica, Geophys. Res. Lett. 38, L16709, doi:10.1029/2011GL048635, 2011.

Jahren, A. H. and Sternberg, L. S. L.: Eocene meridional weather patterns reflected in the oxygen isotopes of Arctic fossil wood, GSA Today 12, 4-9, 2002. 
Jahren, A. H. and Sternberg, L. S. L.: Annual patterns within tree rings of the Arctic middle Eocene (ca. $45 \mathrm{Ma}$ ): isotopic signatures of precipitation, relative humidity, and deciduousness, Geology, 36, 99-102, 2008.

Jasechko, S., Sharp, Z. D., Gibson, J. J., Birks, J. S., Yi, Y., and Fawcett, P. J.: Terrestrial water fluxes dominated by transpiration, Nature, 496, 347-350, 2013.

Jia, X., Lin, H., and Derome, J.: The influence of tropical Pacific forcing on the Arctic Oscillation, Clim. Dynam., 32, 495-509, 2009.

Johnstone, J. A., Roden, J. S., and Dawson, T. E.: Oxygen and carbon stable isotopes in coast redwood tree rings respond to spring and summer climate signals, J. Geophys. Res.-Biogeo., 118, 1438-1450, 2013.

Laskar, J., Fienga, A., Gastineau, M., and Manche, H.: La2010: A new orbital solution for the long term motion of the Earth, Astron. Astrophys., 532, A89, doi:10.1051/0004-6361/201116836, 2011.

Libby, L. M. and Pandolfi, L. J.: Temperature dependence of isotope ratios in tree rings, P. Natl. Acad. Sci. USA, 71, 2482-2486, 1974.

Libby, L. M., Pandolfi, L. J., Payton, P. H., Marshall, J. III., Becker, B., and Giertz-Sienbenlist, V.: Isotopic tree thermometers, Nature, 261, 284-288, 1976.

Liu, X., Shao, X., Liang, E., Zhao, L., Chen, T., Qin, D., and Ren, J.: Species-dependent responses of juniper and spruce to increasing $\mathrm{CO}_{2}$ concentration and to climate in semi-arid and arid areas of northwestern China, Plant Ecol., 193, 195-209, 2007.

Liu, X., An, W., Leavitt, S. W., Wang, W., Xu, G., Zeng, X., and Qin, D.: Recent strengthening of correlations between tree-ring $\delta^{13} \mathrm{C}$ and $\delta^{18} \mathrm{O}$ in mesic western China: Implications to climatic reconstruction and physiological responses, Global Planet Change, 113, 23-33, 2014.

Lomax, B. H., Knight, C. A., and Lake, J. A.: An experimental evaluation of the use of $\mathrm{C}_{3} \delta^{13} \mathrm{C}$ plant tissue as a proxy for the paleoatmospheric $\delta^{13} \mathrm{CO}_{2}$ signature of air, Geochem. Geophys. Geosys., 13, Q0AI03, doi:10.1029/2012GC004174, 2012.

Majoube, M.: Fractionement en oxygéne-18 et en deutérium entre l'eau et sa vapeur, J. Chem. Phys., 197, 1423-1426, 1971.

Mann, M. and Lees, J.: Robust estimation of background noise and signal detection in climatic time series, Climate Change, 33, 409-335, 1996.

Mantua, N. J., Hare, S. R., Zhang, Y., Wallace, J. M., and Francis, R. C.: A Pacific interdecadal climate oscillation with impacts on salmon production, B. Am. Meteorol. Soc., 78, 1069-1079, 1997.

McCarroll, D. and Loader, N. J.: Stable isotopes in tree rings, Quaternary Sci. Rev., 23, 771-801, 2004.

McCarroll, D., Gagen, M. H., Loader, N. J., Robertson, I., Anchukaitis, K., Los, S., Young, G. H. F., Jalkanen, R., Kirchhefer, A., and Waterhouse, J. S.: Correction of tree ring stable carbon isotope chronologies for changes in carbon dioxide content of the atmosphere, Geochim. Cosmochim. Ac., 73, 1539-1547, 2009.

Reinhardt, K., Smith, W. K., and Carter, G. A.: Clouds and cloud immersion alter photosynthetic light quality in a temperate mountain cloud forest, Botany, 88, 462-470, 2010.

Richter, S. L., Johnson, A. H., Dranoff, M. M., LePage, B. A., and Williams, C. J.: Oxygen isotope ratios in fossil wood cel- lulose: Isotopic composition of Eocene- to Holocene-aged cellulose, Geochim. Cosmochim. Ac., 72, 2744-2753, 2008a.

Richter, S. L., Johnson, A. H., Dranoff, M. M., and Taylor, K. D.: Continental-scale patterns in modern wood cellulose $\delta^{18} \mathrm{O}$ : Implications for interpreting paleo-wood cellulose $\delta^{18} \mathrm{O}$, Geochim. Cosmochim. Ac., 72, 2735-2743, 2008b.

Ritchie, R. J.: Modelling photosynthetic photon flux density and maximum potential gross photosynthesis, Photosynthetica, 48, 596-609, 2010.

Roden, J. S., Lin, G., and Ehleringer, J. R.: A mechanistic model for interpretation of hydrogen and oxygen ratios in tree-ring cellulose, Geochim. Cosmochim. Ac., 64, 21-35, 2000.

Roden, J. S., Johnstone, J. A., and Dawson, T. E.: Intra-annual variation in the stable oxygen and carbon isotope ratios of cellulose in tree rings of coast redwood (Sequoia sempervirens), Holocene, 19, 189-197, 2009.

Roden, J. S. and Farquhar, G. D.: A controlled test of the dualisotope approach for the interpretation of stable carbon and oxygen isotope ratio variation in tree rings, Tree Physiol. 32, 490503, 2012.

Royer, D. L.: Estimating latest Cretaceous and Tertiary atmospheric $\mathrm{CO}_{2}$ from stomatal indices, in: Causes and Consequences of Globally Warm Climates in the Early Paleogene, edited by: Wing, S. L., Gingerich, P. D., Schmitz, B., and Thomas, E., Boulder, Colorado, Geological Society of America Special Paper, 369, 79-93, 2003.

Royer, D. L.: $\mathrm{CO}_{2}$-forced climate thresholds during the Phanerozoic, Geochim. Cosmochim. Ac., 70, 5665-5675, 2006.

Saurer, M., Siegenthaler, U., and Schweingruber, H. F.: The climatecarbon isotope relationship in tree rings and the significance of site conditions, Tellus B, 47, 320-330, 1995.

Saurer, M., Aellen, K., and Siegwolf, R.: Correlating $\delta^{13} \mathrm{C}$ and $\delta^{18} \mathrm{O}$ in cellulose of trees, Plant. Cell Environ., 20, 1543-1550, 1997.

Saurer, M., Siegwolf, R. T. W., and Schweingruber, F. H.: Carbon isotope discrimination indicates improving water-use efficiency of trees in northern Eurasia over the last 100 years, Glob. Change Biol., 10, 2109-2120, 2004.

Scheidegger, Y., Saurer, M., Bahn, M., and Siegwolf, R.: Linking stable oxygen and carbon isotopes with stomatal conductance and photosynthetic capacity: A conceptual model, Oecologia, 125, 350-357, 2000.

Schubert, B. A. and Jahren, A. H.: The effect of atmospheric $\mathrm{CO}_{2}$ concentration on carbon isotope fractionation in $\mathrm{C}_{3}$ land plants, Geochim. Cosmochim. Ac., 96, 29-43, 2012.

Schubert, B. A. and Jahren, A. H.: Reconciliation of marine and terrestrial carbon isotope excursions based on changing atmospheric $\mathrm{CO}_{2}$ levels, Nat. Commun., 4, 1-6, 2013.

Sewall, J. O. and Sloan, L. C.: Equable Paleogene climates: The result of a stable, positive Arctic Oscillation?, Geophys. Res. Lett., 28, 3693-3695, 2001.

Simard, S., Morin, H., Krause, C., Buhay, W. M., and Treydte, K.: Tree-ring widths and isotopes of artificially defoliated balsam firs: A simulation of spruce budworm outbreaks in Eastern Canada, Environ. Exp. Bot., 81, 44-54, 2012.

Stokes, M. A. and Smiley, T. L.: An Introduction to Tree-Ring Dating, Univ. of Chicago Press, Chicago, 73 pp., 1968.

Sunderlin, D., Loope, G., Parker, N. E., and Williams, C. J.: Paleoclimatic and paleoecological implications of a Paleocene-Eocene 
fossil leaf assemblage, Chickaloon Formation, Alaska. Palaios, 26, 335-345, 2011.

Tipple, B. J., Meyers, S. R., and Pagani, M.: Carbon isotope ratio of Cenozoic $\mathrm{CO}_{2}$ : A comparative evaluation of available geochemical proxies, Paleoceanography, 25, PA3202, doi:10.1029/2009PA001851, 2010.

Urban, O., Klem, K., Ač, A., Havránková, K., Holišová, P., Navrátil, M., Zitová, M., Kozlová, K., Pokorný, R., Šprtová, M., Tomášková, I., Špunda, V., Grace, J. Impact of clear and cloudy sky conditions on the vertical distribution of photosynthetic $\mathrm{CO}_{2}$ uptake within a spruce canopy, Funct. Ecol., 26, 46-55, 2012.

Vautard, R. and Ghil, M.: Singular spectrum analysis in nonlinear dynamics, with applications to paleoclimatic time series, Physica D, 32, 395-424, 1989.

Vowinckel, T., Oechel, W. C., and Boll, W. G.: The effect of climate on the photosynthesis of Picea mariana at the subarctic tree line, 1. Field measurements, Can. J. Bot., 53, 604-620, 1975.

Wallin, G. and Skärby, L.: The influence of ozone on the stomatal and non-stomatal limitation of photosynthesis in Norway spruce, Picea abies (L.) Karst, exposed to soil moisture deficit, Trees, 6, 128-136, 1992.

Weijers, J. W. H., Schouten, S., Sluijs, A., Brinkhaus, H., and Sinninghe Damsté, J. S.: Warm arctic continents during the Palaeocene-Eocene thermal maximum, Earth Planet Sci. Lett., 261, 230-238, 2007.

Werner, R. A., Kornexl, B. E., Roßmann, A., and Schmidt, H. L.: On-line determination of $\delta^{18} \mathrm{O}$-values of organic substances, Anal. Chim. Ac., 319, 159-164, 1996.
Williams, C. J.: High-latitude Forest Structure: Methodological Considerations and Insights on Reconstructing High-latitude Fossil Forests, Bull. Peabody. Mus. Nat. Hist., 48, 339-357, 2007.

Williams, C. J., Johnson, A. H., LePage, B. A., Vann, D. R., and Sweda, T.: Reconstruction of Tertiary Metasequoia forests, II, Structure, biomass, and productivity of Eocene floodplain forests in the Canadian Arctic, Paleobiology, 29, 271-292, 2003.

Wolfe, A. P., Csank, A. Z., Reyes, A. V., McKellar, R. C., Tappert, R., and Muehlenbachs, K.: Pristine Early Eocene wood buried deeply in kimberlite from northern Canada, PLoS ONE 7, e45537, doi:10.1371/journal.pone.0045537, 2012.

Woodward, F. I.: Ecophysiological studies on the shrub Vaccinium myrtillus L. taken from a wide altitudinal range, Oecologia, 70, 580-586, 1986.

Woodward, F. I.: Stomatal numbers are sensitive to increases in $\mathrm{CO}_{2}$ from preindustrial levels, Nature, 327, 617-618, 1987.

Young, G. H. F., McCarroll, D., Loader, N. J., and Kirchhefer, A. J.: A 500-year record of summer near-ground solar radiation from tree-ring stable carbon isotopes, Holocene, 20, 315-324, 2010.

Young, G. H. F., McCarroll, D., Loader, N. J., Gagen, M. H., Kirchhefer, A. J., and Demmler, J. C.: Changes in atmospheric circulation and the Arctic Oscillation preserved within a millennial length reconstruction of summer cloud cover from northern Fennoscandia, Clim. Dynam., 39, 495-507, 2012.

Zachos, J., Pagani, M., Sloan, L., Thomas, E., and Billups, K.: Trends, rhythms, and aberrations in global climate $65 \mathrm{Ma}$ to present, Science, 292, 686-693, 2001. 